Article

\title{
Investigating Fold-River Interactions for Major Rivers Using a Scheme of Remotely Sensed Characteristics of River and Fold Geomorphology
}

\author{
Kevin P. Woodbridge ${ }^{1}$, Saied Pirasteh ${ }^{2, *}$ (D) and Daniel R. Parsons ${ }^{1}$ \\ 1 Energy and Environment Institute, Faculty of Science and Engineering, University of Hull, \\ Cottingham Road, Hull HU6 7RX, UK \\ 2 Department of Surveying and Geoinformatics, Faculty of Geosciences and Environmental \\ Engineering (FGEE), Southwest Jiaotong University, Chengdu 611756, China \\ * Correspondence: sapirasteh@swjtu.edu.cn; Tel.: +86-1318-3819-193
}

Received: 10 July 2019; Accepted: 24 August 2019; Published: 29 August 2019

\begin{abstract}
There are frequently interactions between active folds and major rivers (mean annual water discharges $>70 \mathrm{~m}^{3} \mathrm{~s}^{-1}$ ). The major river may incise across the fold, to produce a water gap across the fold, or a bevelling (or lateral planation) of the top of the fold. Alternatively, the major river may be defeated to produce a diversion of the river around the fold, with wind gaps forming across the fold in some cases, or ponding of the river behind the fold. Why a river incises or diverts is often unclear, though influential characteristics and processes have been identified. A new scheme for investigating fold-river interactions has been devised, involving a short description of the major river, climate, and structural geology, and 13 characteristics of river and fold geomorphology: (1) Channel width at location of fold axis, $w$, (2) Channel-belt width at location of fold axis, $c b w$, (3) Floodplain width at location of fold axis, fpw, (4) Channel sinuosity, Sc, (5) Braiding index, BI, (6) General river course direction, RCD, (7) Distance from fold core to location of river crossing, C-RC, (8) Distance from fold core to river basin margin, C-BM, (9) Width of geological structure at location of river crossing, Wgs, (10) Estimate of erosion resistance of surface sediments/rocks and deeper sediments/rocks in fold, ERs, ERd, (11) Channel water surface slope at location of fold axis, s, (12) Average channel migration rate, $\mathrm{Rm},(13)$ Estimate of fold total uplift rate, TUR. The first 10 geomorphological characteristics should be readily determinable for almost all major rivers using widely available satellite imagery and fine scale geological maps. This use of remote sensing allows a large number of major rivers to be investigated relatively easily, including those in remote or inaccessible areas, without recourse to expensive fieldwork. The last three geomorphological characteristics should be determinable for most major rivers where other data sources are available. This study demonstrates the methodology of this scheme, using the example of the major rivers Karun and Dez interacting with active folds in the foreland basin tectonic setting of lowland south-west Iran. For the rivers Karun and Dez (mean annual water discharges $575 \mathrm{~m}^{3} \mathrm{~s}^{-1}$ and $230 \mathrm{~m}^{3} \mathrm{~s}^{-1}$, respectively), it was found that geomorphological characteristics Nos. 2, 3 and 7 had statistically significant differences ( $p$-value $\leq 0.05$ ) between the categories of river incision across a fold and river diversion around a fold. This scheme should be used to investigate a variety of major rivers from across the globe. By comparing the same parameters for different major rivers, a better understanding of fold-river interactions will be achieved.
\end{abstract}

Keywords: major river; fold; geomorphology; interactions; remote sensing; characteristics; Karun; Dez; Iran 


\section{Introduction}

Interpreting the interactions between rivers and tectonics can be challenging. Principally, this is because rivers are inherently variable and complex, influenced by a wide range of both autogenic factors that include topography, hydrology and sedimentology, and allogenic factors that include structural geology and active tectonics, plus human activities, climate and relative sea-level (or base level) changes [1-9]. Disentangling the various internal and external factors and their influences on geomorphology can be difficult. However, for major rivers, with mean annual water discharges of $70 \mathrm{~m}^{3} \mathrm{~s}^{-1}$ or more [10], interacting with active folds over horizontal spatial scales of metres to tens of kilometres (river channel dimensions to fold dimensions), the difficulties are lessened, especially at locations upstream of coastal plain-valleys [11-13]. This is because for a single major river at such scales, climate and rates of sediment supply from the basin hinterland are likely to be similar, as climate zones typically extend over scales of hundreds of kilometres [14-16], and upstream of the extent of the backwater length (typically a distance of more than $150 \mathrm{~km}$ from the shoreline) the influences of relative sea-level changes are likely to be minimal $[12,17,18]$. Hence, at these river reach scales, the significant allogenic factors will be limited to tectonics and human activities, with prominent human impacts being limited to the last few millennia [13,19-21].

Major rivers frequently interact with active folds, particularly as transverse rivers in foreland basin systems, where folds oriented roughly parallel to the orogenic axis may form a succession of "obstacles" to river courses, particularly in the orogenic wedge and foredeep [22,23]. Conceptual models of the interactions between transverse rivers and growing folds have been constructed [22,24-28]. Such models indicate that where rates of river aggradation exceed rates of structural uplift associated with the fold, a river will flow without impedance across the fold and may bevel off the top of the emerging fold with little or no topographic relief developing $[27,28]$. Where a fold does develop a surface topographic expression, a river will either flow across the fold by maintaining basinward-dipping channel slopes across the fold, or it will be defeated by the growing fold. To maintain a transverse course across a fold, a river needs sufficient stream power to erode and incise into the crest and across the axis of the fold at a rate greater than the difference between the rates of structural uplift and the rates of river aggradation [22,29]. Whilst the precise controls on river erosion are debated, due to factors such as bed armouring [30,31], it is likely that river erosion into bedrock and sediments will increase with stream power. If the river is defeated, then it will be diverted around the fold by channel migrations or avulsions to flow through structural low points, frequently flowing initially roughly parallel to the fold axis and thence around the nose of the fold. Alternatively, the river may be ponded in a basin upstream of the fold $[22,25,27,32]$.

According to such conceptual models, the responses of rivers and major rivers should be fairly predictable. A river may incise across an active fold as a water gap (a river valley of a maintained river course) or it may be defeated by the fold and diverted to leave a wind gap (a dry valley of a previous river course), with the configuration of these water and wind gaps varying with a number of factors, such as the type of fold $[22,27,33,34]$. For instance, detachment folds would be expected to have a wind gap near the centre of the fold and a water gap near the propagating fold tip, whilst fault bend folds would be expected to a have a number of wind gaps across the length of the fold, with the defeated rivers diverted parallel to the fold axis $[33,34]$. Whilst conceptually it is clear that a major river should incise across an active fold in some cases and divert around it in other cases, in practice it is often unclear as to how and why this occurs. For instance, there is a seemingly paradoxical tendency for a number of major rivers to transect many growing anticlines in the vicinity of their greatest structural and topographic relief [35-37]. By contrast, some rivers frequently cross a growing fold near to the laterally propagating tip or nose of the fold $[27,38]$. Alternatively, rivers may be diverted around the fold tips of laterally propagating anticlinal fold segments until these fold segments coalesce; after which the river may divert to feed a longitudinal river or it may incise across the coalesced fold at the topographic low of the merger location [39]. 
These different responses are probably due to changes in the fold-river interactions with time and the variable and complex nature of river systems $[8,13,40,41]$. There may be different reaction, relaxation and recurrence times for events [42], multiple processes may act in combination to produce a specific phenomenon [42,43], different factors may result in similar effects [41], a river system may not adjust in a progressive and systematic fashion to modifications [44], and a river system may be dominated by autogenic processes and exhibit variability independent of external factors, due to systems of non-linearity or self-organised criticality $[9,44,45]$. Nevertheless, with such systems there may be characteristics of the river or the fold which act as thresholds which the river needs to cross for the dynamic equilibrium of river incision across an active fold to develop and be maintained [42].

The characteristics which may act as thresholds will probably include those associated with the main controlling variables for the persistence of an antecedent river across a growing fold, as shown in Table $1[22,25,28]$.

Table 1. The main controlling variables for the persistence of antecedent rivers crossing growing folds (Modified from $[22,25,28])$.

\begin{tabular}{|c|c|}
\hline Variable & Effect \\
\hline $\begin{array}{l}\text { Rate of sediment aggradation and } \\
\text { rate of structural uplift }\end{array}$ & $\begin{array}{l}\text { Lower rates of sediment aggradation and lower rates of structural uplift } \\
\text { promote persistence of an antecedent river, due to less erosion of the } \\
\text { fold hanging wall being required }\end{array}$ \\
\hline $\begin{array}{l}\text { Erosion resistance of rocks and } \\
\text { sediments within fold }\end{array}$ & $\begin{array}{l}\text { Lower erosion resistances (thick alluvial strata, poor cementation and } \\
\text { readily erodible bedrock) mean that lower stream power are required, } \\
\text { thus promoting persistence of an antecedent river }\end{array}$ \\
\hline Water discharge of river & $\begin{array}{l}\text { Higher water discharges and higher stream power promote persistence } \\
\text { of an antecedent river }\end{array}$ \\
\hline $\begin{array}{l}\text { Stream power, flow depth, channel } \\
\text { width, channel water surface slope } \\
\text { of river }\end{array}$ & $\begin{array}{l}\text { Higher stream power promote persistence of an antecedent river. } \\
\text { Narrower channel widths and steeper channel water surface slopes } \\
\text { promote persistence of the antecedent river, due to associated increased } \\
\text { stream power }\end{array}$ \\
\hline Sediment load & $\begin{array}{l}\text { Increased sediment load decreases proportion of stream power available } \\
\text { for bed erosion, mantling of the bed with sediment precludes erosion of } \\
\text { bed; thus, reduced sediment load may promote persistence of an } \\
\text { antecedent river }\end{array}$ \\
\hline Width of geological structure & $\begin{array}{l}\text { Widening of a geological structures causes reduced channel water } \\
\text { surface slopes and stream power; thus, narrower geological structures } \\
\text { promote persistence of an antecedent river }\end{array}$ \\
\hline Transverse structures & $\begin{array}{l}\text { Transverse structures, such as faults, provide zones of less erosion } \\
\text { resistant rocks that cut across structures, exploited by antecedent rivers }\end{array}$ \\
\hline
\end{tabular}

The influences of some of these controlling variables are quite intricate, particularly those associated with river hydrology and sediment load [31]. For instance, a river crossing a fold will produce aggradation upstream and downstream of the fold in a dynamic equilibrium, in which sufficient foreland-dipping channel slopes for producing erosive stream power across the zone of greatest fold uplift are maintained [22,27,46,47]. If upstream or downstream aggradation is insufficient, as may be the case with reduced sediment load, then the river may be defeated and diverted around the fold [22,24]. If upstream aggradation is excessive, then the river may be defeated by producing slopes that promote channel migrations or avulsions to other upstream locations [27,38,48]. If downstream aggradation is excessive, then the river may also be defeated by reducing channel slopes to such an extent that stream power are insufficient to maintain erosion into the fold and maintain transport away of the eroded material [47,49]. Nevertheless, Table 1 still provides an adequate foundation for differentiating between river incision across a fold and river diversion around a fold. Some of the controlling variables, such as stream power, flow depth, and sediment load, involve characteristics 
which need to be determined by fieldwork; whereas other controlling variables, such as width of geological structure, involve characteristics which can be determined relatively easily from remote sensing imagery and fine scale geological maps.

\subsection{Aim of the Study-A Scheme for Investigating Fold-River Interactions Using Remote Sensing}

The aim of this study is to demonstrate a new scheme which uses a short description of the major river and 13 remotely sensed characteristics of river and fold geomorphology to investigate fold-river interactions. The short description of the major river should include river measurements (including mean annual discharge) and short descriptions of the river course, climate, and structural geology. The first 10 geomorphological characteristics should be readily determinable from widely available remote sensing imagery and fine scale geological maps. This use of remote sensing allows a large number of major rivers to be investigated relatively easily, including those in remote or inaccessible areas, without recourse to expensive fieldwork. The last three geomorphological characteristics should be determinable where additional data sources are available. This study utilises the example of the major rivers Karun and Dez interacting with folds in lowland south-west Iran to show how to apply the scheme in practice.

\subsection{Selection of 13 Remotely Sensed Characteristics of River and Fold Geomorphology}

Remote sensing imagery and fine-scale geological maps have the advantage of being widely available data sources which only need processing for interpretation, rather than detailed fieldwork, but have the drawback that certain parameters, such as sediment grain size, sediment load, flow velocity, and channel depth, cannot be measured accurately from them. A number of the controlling variables in Table 1 involve geomorphological characteristics which are readily determinable from remote sensing and fine scale geological and topographical maps, as are other significant geomorphological characteristics, such as channel width, that are associated with other conceptual models [22,25-28]. Also, previous detailed studies on interactions between specific major rivers and tectonics, particularly those of Jorgensen [50] involving rivers in western U.S.A., Lavé and Avouac [51,52] involving upland rivers in Nepal, and Woodbridge [13] involving lowland rivers in south-west Iran, have identified useful characteristics determinable using remote sensing and geological maps in their investigations of such interactions. All of these data sources have been used to compile a suite of 13 useful geomorphological characteristics to be determined in investigations of fold-river interactions:

(1) Channel width at location of fold axis, $w$

(2) Channel-belt width at location of fold axis, $c b w$

(3) Floodplain width at location of fold axis, fpw

(4) Channel sinuosity, $S c$

(5) Braiding index, $B I$

(6) General river course direction, $\mathrm{RCD}$

(7) Distance from fold core to location of river crossing, C-RC

(8) Distance from fold core to river basin margin, C-BM

(9) Width of geological structure at location of river crossing, Wgs

(10) Estimate of erosion resistance of surface sediments/rocks and deeper sediments/rocks in fold, ERs, ERd

(11) Channel water surface slope at location of fold axis, $s$

(12) Average channel migration rate, $\mathrm{Rm}$

(13) Estimate of fold total uplift rate, TUR

In summary, channel width at the location of the fold axis should be a useful parameter since the conceptual model of Amos and Burbank [25] and the studies of Lavé and Avouac [51,52] in Nepal indicate that channel width may act as a key characteristic of river responses, with channel narrowing 
to enhance incision rates, apparently taking precedence over other changes for upland rivers crossing rapidly uplifting folds [27,52-54]. Channel-belt width and floodplain width at the location of the fold axis should be useful parameters, since narrowing of the channel-belt and narrowing of the floodplain will increase the proportion of stream power available for vertical erosion and thus promote the maintenance of a river incising across a fold. The study of Woodbridge [13] demonstrated the importance of channel-belt width, with a narrow average channel-belt width of less than c. $2.7 \mathrm{~km}$ being hypothesised as a threshold needed for the rivers Karun and Dez to produce and maintain river incision across a fold in lowland south-west Iran. Channel sinuosity and braiding index should both be useful parameters, since the study of Woodbridge [13] found trends for both reduced sinuosity and braiding index for river reaches incising across a fold; though, as with the studies of Jorgensen [50] in U.S.A. and Zámolyi et al. [55] in Hungary, these trends did not always achieve statistical significance. General river course direction should be a useful parameter, as the study of Woodbridge [13] found a tendency for river incision across a fold to have a general river course direction orthogonal to the fold axis for the river reaches which crossed the fold, whereas river diversion had a general river course parallel to the fold axis upstream of the fold, followed by a change in river course bearing of about $20^{\circ}-70^{\circ}$ to flow around the fold.

Distance from the fold core to the location where the river crosses the fold axis should be a useful discriminative parameter since, naturally, there is very strong tendency for river incision across a fold to occur between the fold core and the fold nose, and for river diversion to occur beyond the fold nose $[13,20,56]$. Distance from the fold core to the river basin margin, should be a useful parameter if the timing of initial fold-river interactions is important, as hypothesised by Woodbridge [13]. Where a river incises across a fold due to it initially encountering the fold as a small, emerging fold, the fold core location is likely to be within the margins of the drainage basin of the river crossing the fold axis (positive measurement); whereas where a river diverts around a fold due to it initially encountering the fold as a larger, more developed fold, the fold core location is likely to be beyond the margins the drainage basin of the river crossing the fold axis, or its projection (negative measurement) $[13,20]$. Width of geological structure should be a useful parameter, since, as shown in Table 1, the conceptual model of Burbank et al. [22] indicates that narrow geological structures promote river incision across a fold by avoiding the reduced channel slopes, stream power, and vertical erosion associated with widening geological structures. The erosion resistances of sediments and rocks in a fold can be estimated from fine scale geological maps where details of the sediments and rock types are known, and should be useful parameters since the conceptual models of Burbank et al. [22] and Bufe et al. [28] indicate that low erosion resistances promote river incision across a fold and river bevelling of the top of a fold. Also, some studies, such as that on the meandering of the River Dniester by Yeromenko and Ivanov [57], have found that variations in erosion resistances of rocks and sediments were significant in influencing river responses; though other studies, such as those on rivers and growing folds in northern Alaska reviewed by Burbank et al. [22] have found that variations in erosion resistances were not.

To determine the last three geomorphological characteristics precisely, data sources in addition to one set of remote sensing imagery and one set of fine scale geological maps are preferable. Whilst slope can be measured from a DEM, greater precision for channel water surface slope measurement will be obtained from other data sources, such as precise hydrological and topographical surveys. Channel water surface slope at the location of the fold axis should be a useful parameter, since it was found to be a key characteristic for upland rivers in studies by Lavé and Avouac [51,52] in Nepal, Yanites et al. [58] in Taiwan, and by Amos and Burbank [25] in New Zealand. Average channel migration rate over time intervals of about $20-40$ years should be a useful parameter, since lateral migration rates have been found to be significant in studies of river incision across a fold [13] and river lateral planation of the top of a fold [28]. Fold total uplift rate, as estimated from additional data sources, should be a useful parameter since, in a number of conceptual models, low rates of structural uplift promote the maintenance of a river incising across a fold [22,24,28]. 


\section{Summary of Methods}

There are three main elements to the application of the scheme to a specific major river or river system:

(1) A short description of the river, including its course, and the climate and structural geology of the region through which it flows

(2) Measurement of geomorphological characteristics Nos. 1 to 10

(3) Measurement of geomorphological characteristics Nos. 11 to 13

\subsection{Short Description of River}

The short description of the river introduces the major river and the context of the fold-river interactions. It should include data on river length, drainage basin area, mean annual water discharge, seasonality of discharge, and major direct human impacts on the river, and a short description of the river course. It should also include short descriptions of the regional climate and structural geology, with some details of the tectonic setting and the types of faults and folds. The short description of the river can be supplemented by maps of the river system and structural geology.

\subsection{Measurement of Geomorphological Characteristics Nos. 1 to 10}

The measurement of the first 10 characteristics of river and fold geomorphology provides the main data for investigating different fold-river interactions. The only data sources needed to determine these 10 remotely sensed characteristics are: high-resolution remote sensing images, fine scale geological maps (preferably at 1:100,000 scale or finer), and maps of oil and gas fields and seismic survey sections (in cases where there are sub-surface folds). Such widespread data sources should be available for most of the major rivers of the world.

For characteristics Nos. 1 to 3 (channel width, channel-belt width, and floodplain width), the measurements are made solely at the location of the fold axis or its projection. This is because these characteristics vary continuously along the length of the river and their measurements are not dependent on how the river is sub-divided into river reaches. By contrast, characteristics Nos. 4 and 5 (channel sinuosity and braiding index) are heavily dependent on how the river is sub-divided into river reaches. Hence, for these characteristics the measurements are made for river reaches immediately upstream of the fold, across the fold axis (or its projection), and immediately downstream of the fold. This is done so that changes in these characteristics associated with the fold can be more easily differentiated from changes due to the sub-division into river reaches and other variations. Similarly, for characteristic No. 6 (general river course direction), the measurements are made for river reaches immediately upstream of the fold, across the fold axis (or its projection), and immediately downstream of the fold. For general river course direction, it is changes relative to the fold axis which are more indicative of changes associated with the fold. Hence, these measurements are also made relative to the fold axis, and there is an emphasis on changes in river course direction between river reaches immediately upstream of the fold, across the fold axis, and immediately downstream of the fold. Characteristics Nos. 7 to 10 (distances from the fold core to the river crossing and river basin margin, width of geological structure, and estimate of erosion resistance) are mainly associated with the structural geology, rocks and sediment of the fold. Hence, for these characteristics, the measurements are made relative to structures of the fold, especially the fold core, the fold axis, and the fold limbs.

\subsection{Measurement of Geomorphological Characteristics Nos. 11 to 13}

The measurement of the last three geomorphological characteristics provides additional data for investigating different fold-river interactions. The data sources needed for these characteristics may not be available for all major rivers worldwide, hence they may be considered as supplementary characteristics. The additional data sources could be precise hydrological or topographical surveys of the river, databases superimposing two sets of high-resolution remote sensing imagery separated by 
about $20-40$ years, and data relating to vertical Earth surface movements, such as dating of displaced geomorphic surfaces e.g., [59], repeated precision GPS surveys, and precise levelling e.g., [60].

For characteristic No. 11 (channel water surface slope) the measurements are made solely at the location of the fold axis or its projection. This is because channel water surface slope is highly variable and the fold axis is a key location where similar conditions can be compared. Characteristic No. 12 (average channel migration rate) is heavily dependent on how the river is sub-divided into reaches. Hence, measurements for this characteristic are made for river reaches immediately upstream of the fold, across the fold axis (or its projection), and immediately downstream of the fold. Characteristic No. 13 (fold total uplift rate) is mainly associated with the structural geology of the fold. Hence, the estimates or measurements for this characteristic are made for the crest of the fold relative to the surrounding region.

\section{Details of Methods for the 13 Geomorphological Characteristics, as Applied to the Rivers Karun and Dez}

To introduce and demonstrate the use of the new scheme in practice, it has been applied to the River Karun and River Dez in the province of Khuzestan in lowland south-west Iran, as an example. As shown in Figures 1 and 2, the major rivers Karun and Dez (mean annual water discharges c. $575 \mathrm{~m}^{3} \mathrm{~s}^{-1}$ and $230 \mathrm{~m}^{3} \mathrm{~s}^{-1}$, respectively) flow from the Zagros orogen in the $\mathrm{N}$ and NE across the Upper and Lower Khuzestan Plains into the Mesopotamian-Persian Gulf Foreland Basin to the S and SW [61]. Their interactions with folds within the Upper and Lower Khuzestan Plains have been subjected to detailed investigations, as described by Woodbridge [13], Woodbridge and Frostick [56] and Woodbridge et al. [20]. The data in these investigations was used to provide short descriptions of the rivers Karun and Dez, as given in Section 4.1. The data was also used to demonstrate the measurement of each of the 13 geomorphological characteristics, by using the example of the Sardarabad Anticline (SDA on Figure 2) to the north-west of Band-e Qir Figure 1, and its interactions with the River Dez (river incision across the fold) and the River Karun (Shuteyt branch) (river diversion around the fold). The Sardarabad Anticline appears to be a doubly plunging, segmented, asymmetric detachment fold which is about $58 \mathrm{~km}$ long $\times 9 \mathrm{~km}$ wide, and which rises to more than $70 \mathrm{~m}$ above the surrounding plains. The fold axis is oriented roughly ESE-WNW, curving to SE-NW at the eastern end, where it apparently merges with a roughly N-S oriented oblique lateral ramp [13,62-65]. 

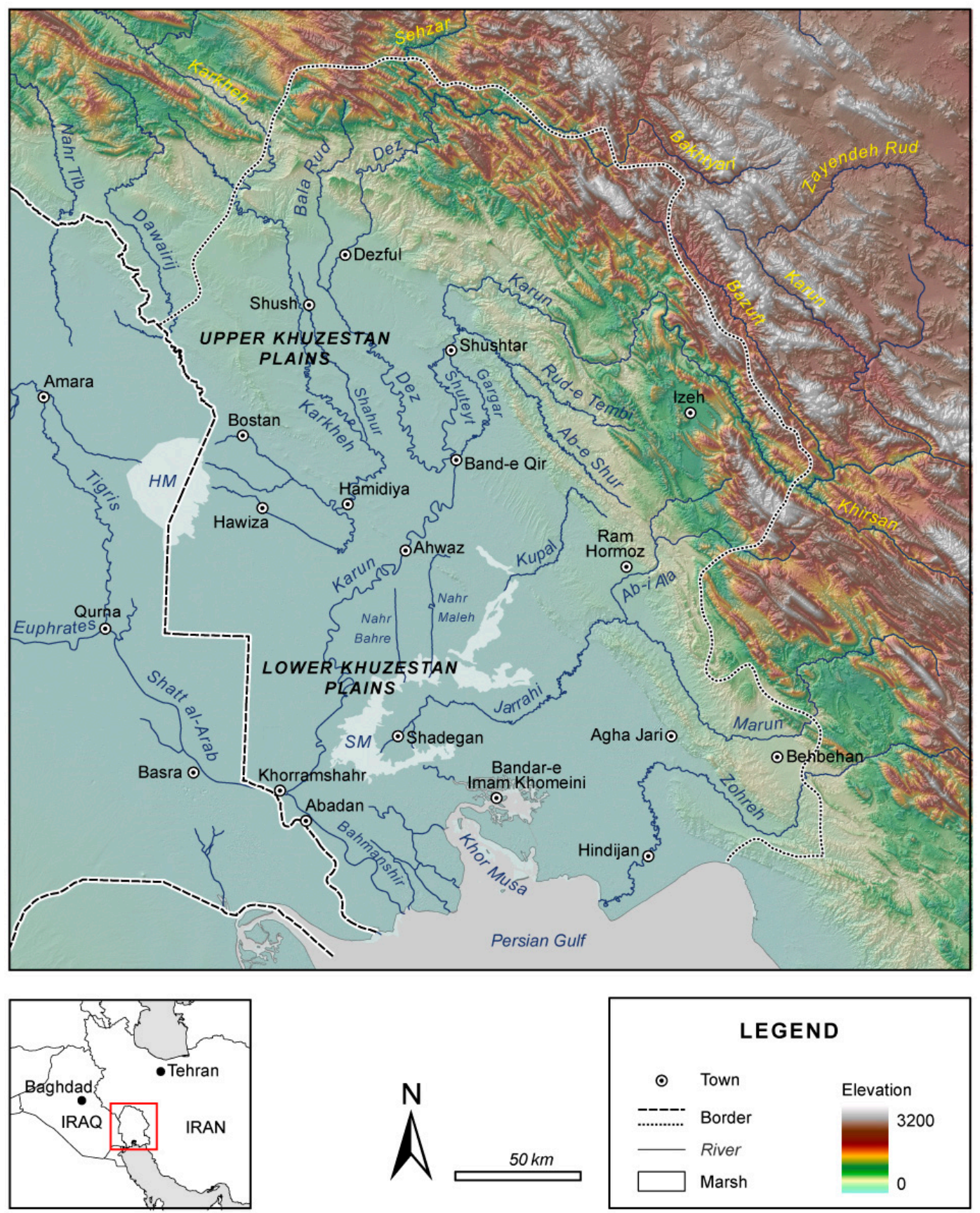

Figure 1. The River Karun, River Dez, and other main rivers of Khuzestan province and its environs (Modified from Heyvaert et al., 2013) [63]. Centred on $31^{\circ} 33^{\prime} \mathrm{N} 49^{\circ} 02^{\prime} \mathrm{E}$. HM Huwayzah marshes $S M$ Shadegan marshes International border Border of Khuzestan province. The Sardarabad Anticline is a $58 \mathrm{~km}$ long fold that is oriented roughly ESE- WNW and located to the north-west of the settlement of Band-e Qir. 


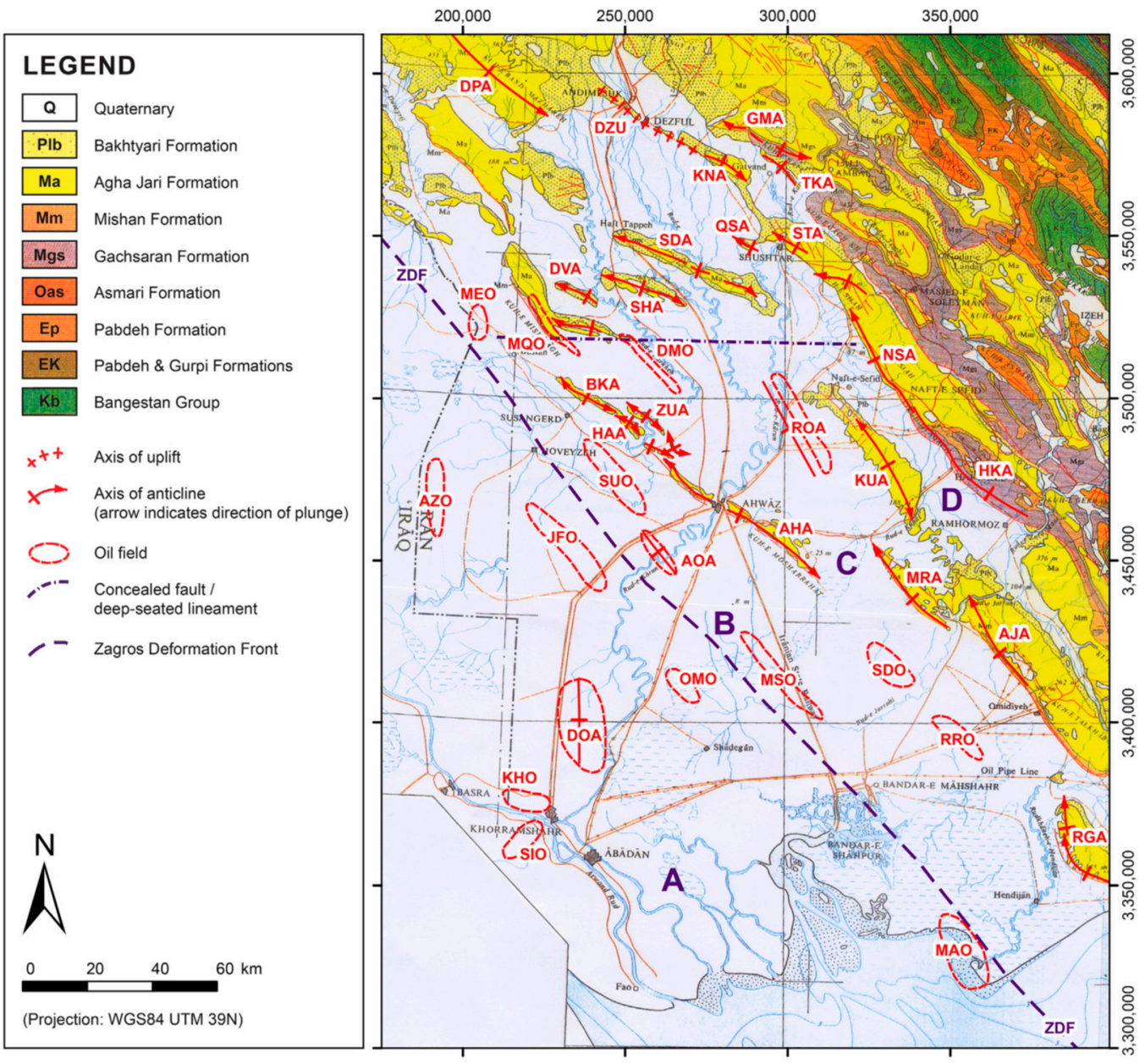

Figure 2. The broad scale geology of south-west Iran, showing selected anticlines, oilfields and oilfield anticlines in the lowlands (Modified from NIOC, 1973, using various sources) [20,64,65]. Centred on $31^{\circ} 14^{\prime} \mathrm{N} 48^{\circ} 46^{\prime}$ E. Structural geology: AGA = Abu ul-Gharib Anticline, AHA = Ahvaz Anticline, AJA = Agha Jari Anticline, AOA = Ab-e Teymur Oilfield Anticline, AZO = Azadegan Oilfield, BKA = Band-e Karkheh Anticline, DMO = Dasht-e Mishan Oilfield, DOA = Dorquain Oilfield Anticline, DPA = Dal Parri Anticline, DVA = Darreh-ye Viza Anticline, DZU = Dezful Uplift, GMA = Gach-e Moh Anticline, HAA = Hamidiyyeh Anticline, HKA = Haft Kel Anticline, $\mathrm{JFO}=$ Jufeyr Oilfield, $\mathrm{KHO}=$ Khorramshahr Oilfield, KNA = Kuhanak Anticline, KUA = Kupal Anticline, $\mathrm{MAO}=$ Mahshahr Oilfield, $\mathrm{MEO}=$ Mehr Oilfield, MQO = Mushtaq Oilfield, MRA = Marun Anticline, MSO = Mansuri Oilfield, NSA = Naft-e Safid Anticline, OMO = Omid Oilfield, QSA = Qal' eh Surkheh Anticline, RGA = Rag-e Safid Anticline, ROA = Ramin Oilfield Anticline, RRO = Ramshir Oilfield, SDA = Sardarabad Anticline, SDO = Shadegan Oilfield, SHA = Shahur Anticline, SIO = Siba Oilfield, STA = Shushtar Anticline, SUO = Susangerd Oilfield, TKA = Turkalaki Anticline, ZDF = Zagros Deformation Front (purple dashed line), ZUA = Zeyn ul-Abbas Anticline. Geology: Q = Quaternary (c. 1 Ma-Present; generally unconsolidated alluvial sands, muds, gravels, and marls). Plb = Bakhtyari Formation (Middle Pliocene to Pleistocene, c. 3 Ma-1 Ma; well-consolidated conglomerates, sandstones, and mudstones). $\mathrm{Ma}=$ Agha Jari Formation (Middle Miocene to Middle Pliocene, c. $10 \mathrm{Ma}-3 \mathrm{Ma}$; sandstones, marls, and mudstones). Mm = Mishan Formation (Middle Miocene, c. $16 \mathrm{Ma}-10 \mathrm{Ma}$; marls, limestones, and sandstones). Mgs = Gachsaran Formation (Early Miocene, c. 23 Ma-16 Ma; anhydrite and salt, limestones, marls, and shales). Oas = Asmari Formation (Oligocene-Early Miocene; mainly limestones). Ep = Pabdeh Formation (Palaeocene-Oligocene; mainly marls and shales). $\mathrm{EK}=$ Pabdeh \& Gurpi Formations (Santonian-Oligocene; mainly marls and shales). Kb = Bangestan Group (Late Cretaceous (Albian-Campanian); mainly limestones) [64-69]. Approximate zones of Earth surface movements: $\mathrm{A}=$ Subsidence, $\mathrm{B}=$ Minimal vertical Earth surface movements, $\mathrm{C}=$ Uplift at rates of approx 0.1-0.8 $\mathrm{mm} \mathrm{yr}^{-}, \mathrm{D}=$ Uplift at rates of approx $0.2-2.3 \mathrm{~mm} \mathrm{yr}^{-}[13,20,56]$. 


\subsection{Measurement of Geomorphological Characteristics Nos. 1 to 10}

For determining these 10 characteristics for the rivers Karun and Dez, the remote sensing images used were $30 \mathrm{~m}$ resolution false-colour Landsat Enhanced Thematic Mapper Plus (ETM+) images (28 July 2001 and 4 August 2001) with Band 4 (near-infrared, 750-900 nm) displayed red, Band 3 (red, 630-690 nm) displayed green, Band 2 (visible green, 525-605 nm) displayed blue, and pan-sharpened with pan-chromatic Band 8 [66]. The fine-scale geological maps used were mainly 1:100,000 scale geological maps, such as "Sheet 20824E Mulla Sani" of the Iranian Oil Operating Companies IOOC [67]. The maps of oil and gas fields and seismic survey sections were from a variety of sources [68-71]. The Landsat ETM+ images and detailed surveys of the rivers undertaken by the Dez Ab Engineering Company from 1997-2000 were used to sub-divide the main river courses of the Karun and Dez from the vicinity of Gotvand and Dezful to the Persian Gulf into a succession of straight-line river reaches. The average river reach length was $8.0 \mathrm{~km}$, with an extreme range of $0.8-50.5 \mathrm{~km}$. A river reach was defined as a length of river channel with a relatively homogeneous discharge and morphology [72]. Significant changes in general river course direction, river planform, and river morphology were used to demarcate the end of one reach and the start of the next. This sub-division into river reaches, whilst necessarily subjective, facilitated the measurement of characteristics associated with river reaches, such as channel sinuosity and general river course direction $[13,20]$.

\subsubsection{Channel Width at Location of Fold Axis (or its Projection)}

Symbol: $w$

Units: $\mathrm{m}$ (quoted to two decimal places)

Measurement location: Where river channel crosses the fold axis (or its projection)

Channel width is defined as the maximum extent of the river channel water surface, as distinguished on remote sensing images (or survey records), measured orthogonal to the river thalweg. Since the channel-forming discharge is commonly taken as the bankfull discharge and channel width varies significantly with river discharge, the aim is to measure the width between the channel banks at bankfull discharge [42,73]. In practice, channel width also varies with distance along the channel, local irregularities and outcrops, vegetation, human impacts, and other factors, so it is recommended that the distance between the channel banks is measured from remote sensing images of a single date, preferably at a time of relatively high flows. Whilst variations could be reduced by determining average channel width over a distance of one or two meander wavelengths [74-76], this is not recommended since subtle changes in channel width would be missed in the frequent cases where the zone of maximal uplift is considerably smaller than the meander wavelength of a major river. Instead, for a single-thread meandering channel pattern, the width of the channel at or very near to the fold axis should be measured, with care to avoid measuring at localised broadening or constriction of the channel. For a multi-thread braided channel pattern, the widths of all channels at the fold axis location should be measured, and the sum recorded. For anastomosing or anabranching channel patterns, the widths of all channels associated with the main branch of the river at the fold axis location should be measured, and the sum recorded [77].

For the example of the River Karun (Shuteyt) diverting around the Sardarabad Anticline, channel width, $w=202,19 \mathrm{~m}$, at the location where the projection of the fold axis intersects with the thalweg of the main river channel, as shown in Figure 3. 


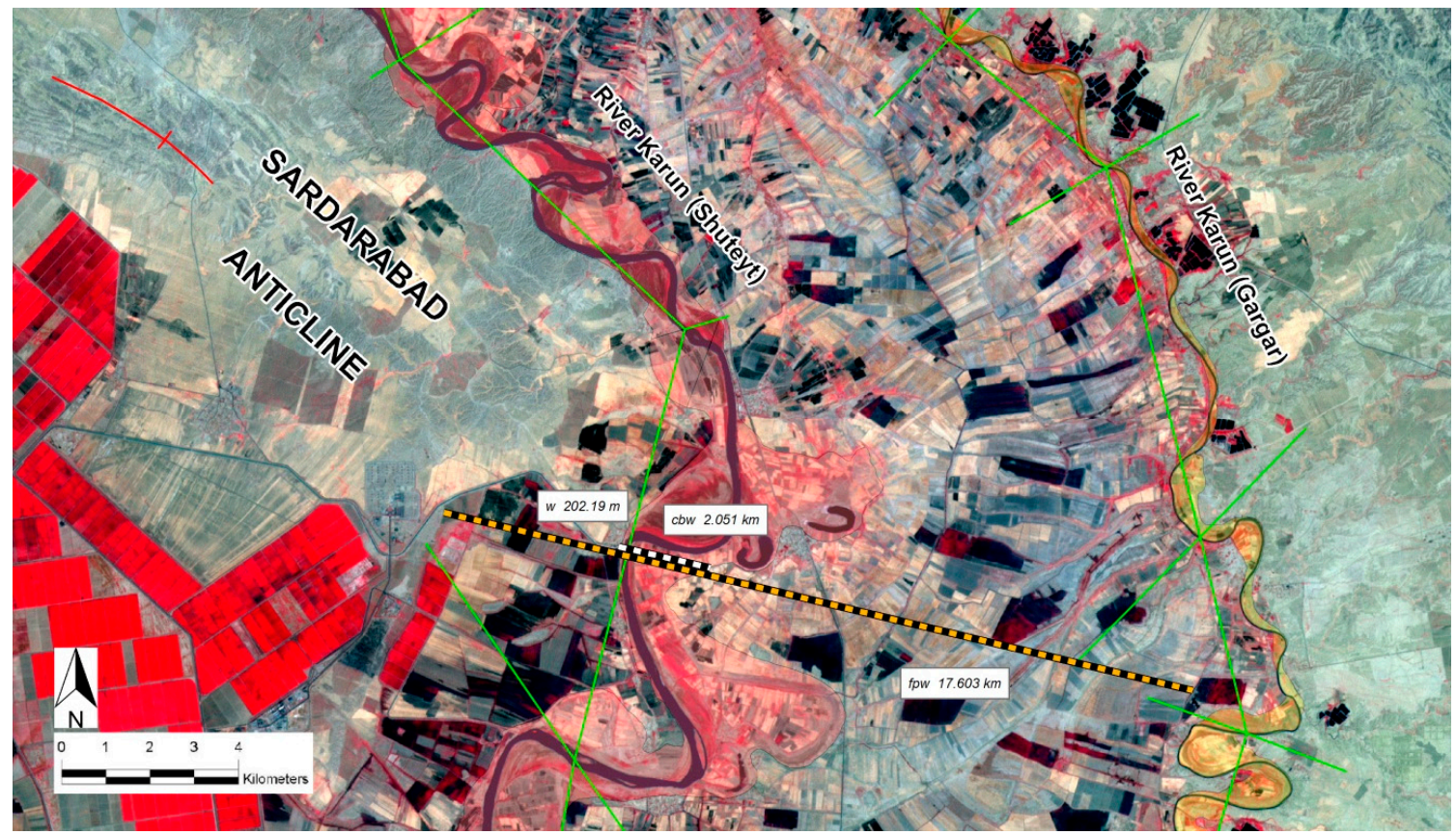

Figure 3. The measurement of $w, c b w$ and fpw (False-colour Landsat image (2001) of the River Karun (Shuteyt branch) diverting around the Sardarabad Anticline, centred on c. $31^{\circ} 52^{\prime} \mathrm{N} 48^{\circ} 53^{\prime} \mathrm{E}$ ). The axis of the anticline is shown as a red line with cross-bar, and straight-line river reaches are shown as thin green lines, with roughly orthogonal thin green lines demarcating successive reaches.

\subsubsection{Channel-Belt Width at Location of Fold Axis (or its Projection)}

Symbol: $c b w$

Units: $\mathrm{km}$ (quoted to three decimal places)

Measurement location: Where river channel crosses the fold axis (or its projection)

Channel-belt width is defined as the maximum extent of the channel-belt of the river, as distinguished on remote sensing images, measured orthogonal to the axis of the river reach. For single-thread meandering and straight channel patterns, the measurement is to the extremities of all channels, abandoned channels, meanders, levées, crevasse channels and splays, oxbows, and meander scars that are associated with the active river channel. For a multi-thread braided channel pattern, the measurement is to the extremities of all channels, bars, islands, and abandoned channels associated with the active river channel [73]. For anastomosing or anabranching channel patterns, the measurement is to the extremities of the main active river channels, with any anabranches clearly separated by floodplain areas being considered as discrete channel-belts not included in the measurement [77]. Where there is uncertainty, such as discriminating between extensive braided rivers and discrete channels of anastomosing rivers, the default is to use the larger channel-belt width measurement.

For the example of the River Karun (Shuteyt) diverting around the Sardarabad Anticline, channel-belt width, $c b w=2.051 \mathrm{~km}$, as shown in Figure 3. In this figure, the channel-belt of the River Karun (Shuteyt) is highlighted in light red (that of the River Gargar is highlighted in yellow), and the channel-belt width measurement is indicated by the white and black checked straight line. The location of the measurement is the same as that for geomorphological characteristic No. 1.

\subsubsection{Floodplain Width at Location of Fold Axis (or its Projection)}

Symbol: fpw

Units: $\mathrm{km}$ (quoted to three decimal places)

Measurement location: Where river channel crosses the fold axis (or its projection) 
Floodplain width is defined as the maximum extent of the floodplain of the river, as distinguished on remote sensing images, measured orthogonal to the axis of the river valley. The floodplain width can vary from the channel-belt width to many tens of channel-belt widths [73]. The margins of the floodplain are usually fairly clear due to a slight change in slope at the base of the enclosing valley walls. Interpretive difficulties with floodplain width may arise where two or more major rivers occupy a large plain, especially a large coastal plain, and, in these cases, the measurement is to the extremities of the floodplain of the streams and wetlands within the drainage basin of the major river in question [78].

For the example of the River Karun (Shuteyt) diverting around the Sardarabad Anticline, floodplain width, $f p w=17.603 \mathrm{~km}$, as shown in Figure 3. In this figure, the floodplain width measurement is indicated by the light brown and black checked straight line. The location of the measurement is the same as that for geomorphological characteristic No. 1.

\subsubsection{Channel Sinuosity}

Symbol: Sc

No units (ratio quoted to three decimal places)

Measurement location: River reaches immediately upstream of fold, across the fold axis (or its projection), and immediately downstream of fold

Channel sinuosity is the ratio defined by the equation $S c=L_{c} / L_{v}$ where $L_{c}$ is channel length $(\mathrm{m})$, and $L_{v}$ is straight-line valley length $(\mathrm{m})$ [42]. The channel length is the total distance between the two ends of the river reach measured along the thalweg of the main channel. For multi-thread braided, anastomosing, and anabranching channel patterns there can be interpretive difficulties regarding the main channel thalweg, though, generally, it should be interpreted as the course of the broadest channel. The straight-line valley length is the distance between the two ends of the river reach measured in a straight line along the axis of the river reach. Measurements are made for river reaches immediately upstream of the fold, across the fold axis (or its projection), and immediately downstream of the fold, to elucidate any changes in channel sinuosity associated with the fold.

For the example of the River Dez incising across the Sardarabad Anticline, channel sinuosity, $S c=1417$ (immediately upstream of fold); 1120 (across fold axis); 1585 (immediately downstream of fold), as shown in Figure 4.

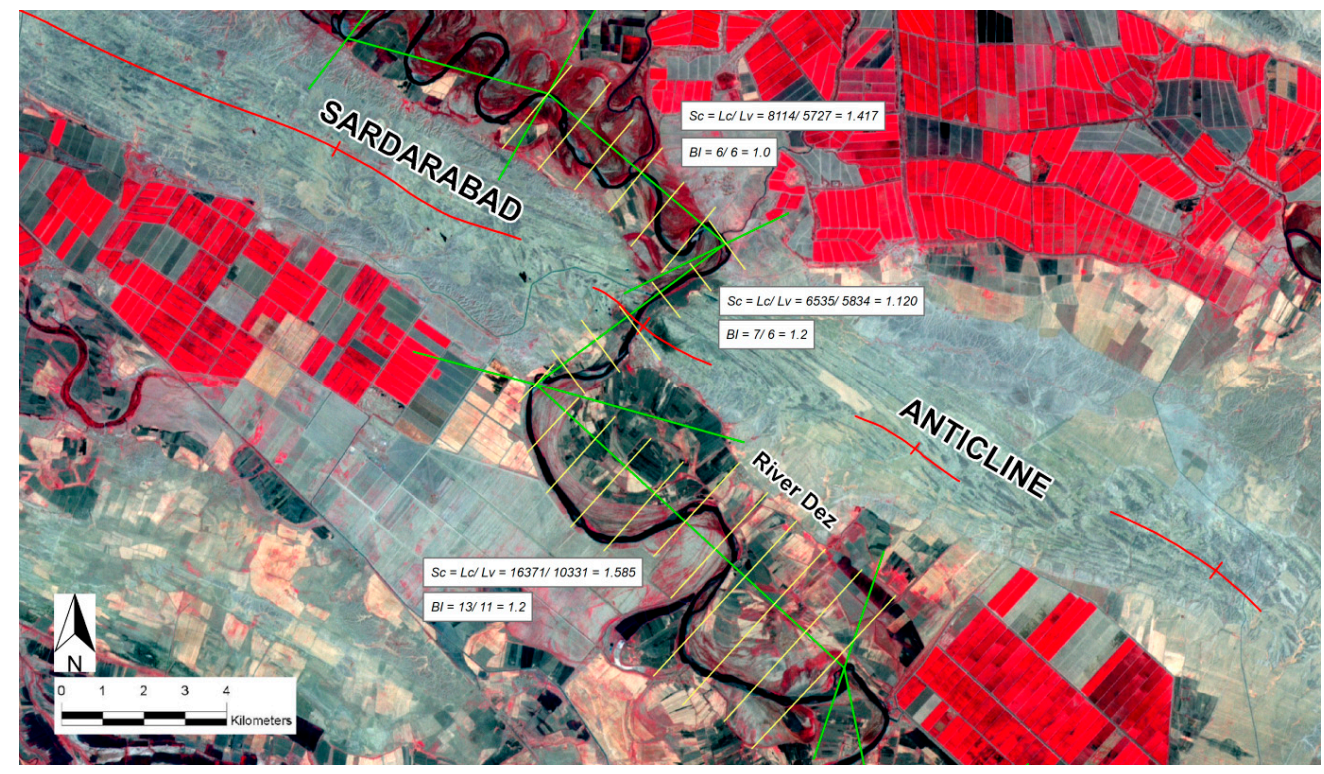

Figure 4. The measurement of $S c$ and BI (False-colour Landsat image (2001) of the River Dez incising across the Sardarabad Anticline, centred on c. $31^{\circ} 57^{\prime} \mathrm{N} 48^{\circ} 36^{\prime} \mathrm{E}$ ). The axis of the anticline is shown as a red line with cross-bar, and straight-line river reaches are shown as thin green lines, with roughly orthogonal thin green lines demarcating successive reaches. 


\subsubsection{Braiding Index}

Symbol: $B I$

No units (index quoted to one decimal place)

Measurement location: River reaches immediately upstream of fold, across the fold axis (or its projection), and immediately downstream of fold

The braiding index is a measure of the intensity of braiding, and for a river reach can be defined as the channel count index of the mean number of anabranches (or links) per river cross-section for that reach $[79,80]$. Since the intensity of braiding varies with flow stage [81], it is recommended that measurements are undertaken from remote sensing images of a single date, preferably at a time of relatively high flows for compatibility with other measurements, such as channel width. The river reach is sub-divided into river cross-sections orthogonal to the valley axis which are approximately $1 \mathrm{~km}$ apart. For each river cross-section, the number of distinct anabranches is counted and the mean for the entire river reach is calculated. For single-thread meandering and straight channel patterns, the braiding index will be 1, or slightly greater than 1 where there are channel islands. For anastomosing or anabranching channel patterns, the braiding index is calculated for the main branch of the river. Measurements are made for river reaches immediately upstream of the fold, across the fold axis (or its projection), and immediately downstream of the fold, to elucidate any changes in braiding index associated with the fold.

For the example of the River Dez incising across the Sardarabad Anticline, braiding index, $B I=1.0$ (immediately upstream of fold); 1.2 (across fold axis); 1.2 (immediately downstream of fold), as shown in Figure 4. In this figure, thin yellow lines indicate the sub-division of each river reach into river cross-sections orthogonal to the valley axis which are $1 \mathrm{~km}$ apart.

\subsubsection{General River Course Direction}

Symbol: RCD

Units: degrees (quoted to the nearest $5^{\circ}$, as a compass bearing in degrees relative to true north, and as a bearing in degrees relative to the fold axis)

Measurement location: River reaches immediately upstream of fold, across the fold axis (or its projection), and immediately downstream of fold

The general river course direction is the general overall direction towards which the river flows for the length of a river reach [13]. This can be gauged "by eye" by carefully viewing the remote sensing images and drawing a straight line of that orientation on the remote sensing image - the orientation of which will be similar to the river reach axes in the vicinity - and then measuring the bearing of that line to the nearest $5^{\circ}$ to avoid false precision.

For the example of the River Dez incising across the Sardarabad Anticline, general river course direction, $\mathrm{RCD}=130^{\circ}\left(10^{\circ}\right.$ to fold axis) (immediately upstream of fold); $230^{\circ}$ ( $70^{\circ}$ to fold axis) (across fold axis); $135^{\circ}$ ( $15^{\circ}$ to fold axis) (immediately downstream of fold), as shown in Figure 5 . In this figure, the general river course direction is indicated by white lines with black arrowheads. 


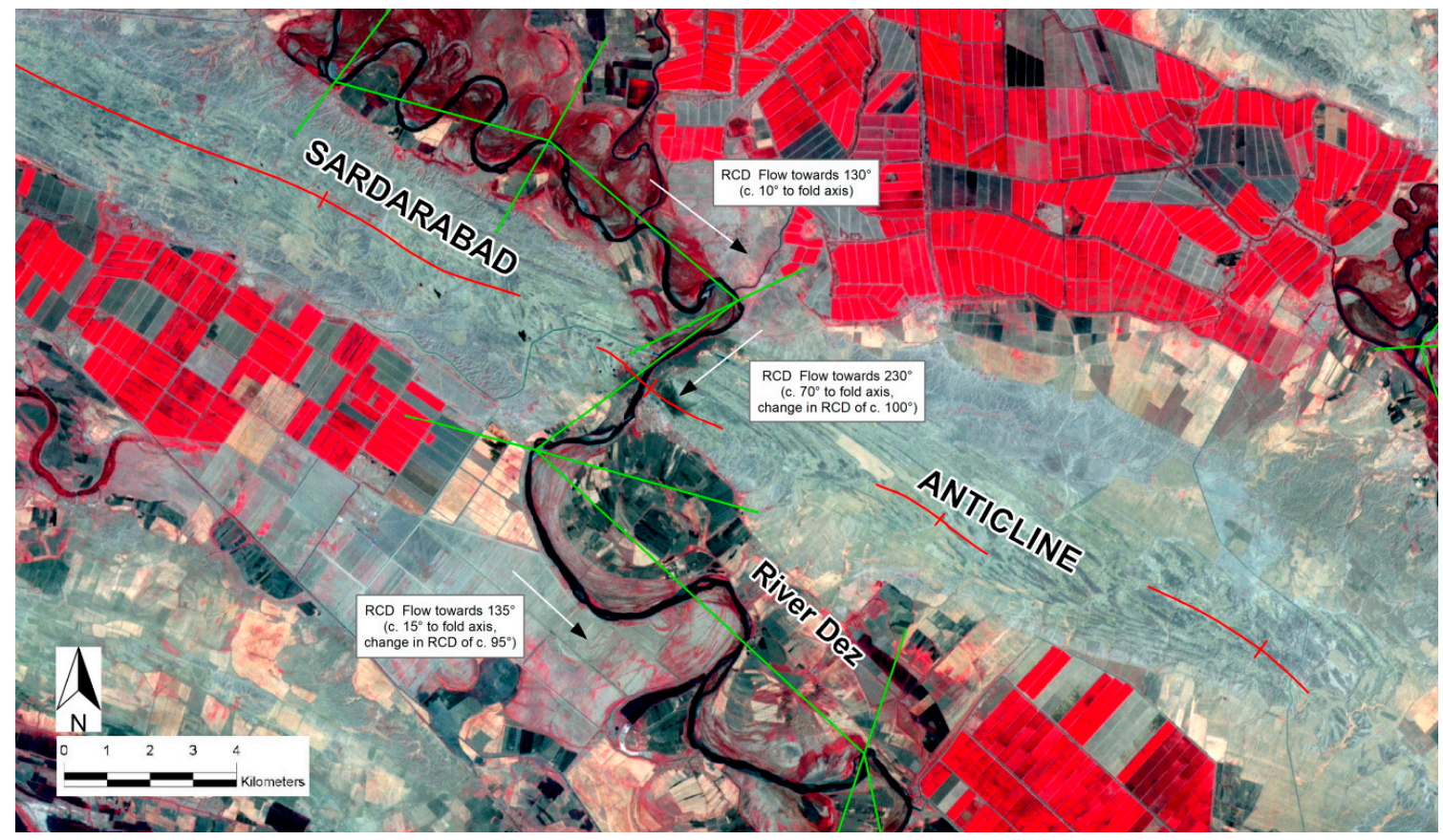

Figure 5. The measurement of $R C D$ (False-colour Landsat image (2001) of the River Dez incising across the Sardarabad Anticline, centred on c. $31^{\circ} 57^{\prime} \mathrm{N} 48^{\circ} 37^{\prime} \mathrm{E}$ ). The axis of the anticline is shown as a red line with cross-bar, and straight-line river reaches are shown as thin green lines, with roughly orthogonal thin green lines demarcating successive reaches.

\subsubsection{Distance From Fold Core to Location of River Crossing}

\section{Symbol: C-RC}

Units: $\mathrm{km}$ (quoted to one decimal place)

Measurement location: Along the fold axis, from the centre of the fold core to where the river channel crosses the fold axis (or its projection)

$\mathrm{C}-\mathrm{RC}$ is defined as the horizontal distance from the centre of the fold core measured along the fold axis, and along the projection of the fold axis, where appropriate), to the location where the river channel thalweg crosses the fold axis or its projection [13]. This is most easily measured on fine scale geological maps (typically 1:100,000 or 1:50,000 scale geological maps, depending on availability) on which the surface lithology, structural geology (including the surface extent and anticlinal axis of each fold), and river channels are accurately shown.

The river crossing location is determined simply from where the fold axis (or its projection) intersects with the thalweg of the main river channel, as indicated on the fine scale geological map or on the remote sensing image. Where the main river channel has more than one intersection with the fold axis, as may be the case with a sinuous river, the intersection that is nearest to the fold core will be considered the river crossing location. The location of the centre of the fold "core" (the centre of the main part of the fold which emerged first on the ground surface) is considerably more difficult to determine, since the detailed developmental history of a fold is usually not known. For ease of measurement, the centre of the fold core should be located on the fold axis. For sub-surface folds with little or no surface topographic expression, known principally from oil and gas field locations and seismic surveys, the centre of the fold core should be interpreted as being midway along the approximate location of the fold axis on the ground surface (with particular consideration of the dip of sub-surface structures and stratigraphy). This interpretation can be modified in cases where the sub-surface structural geology is well known. For young, emerging folds the centre of the fold core can be interpreted with more confidence and will usually be coincident with the centre of the surface topographic expression of the fold. For older, emerged folds the location of the centre of the fold core 
is much less certain. It can generally be interpreted to be in the vicinity of the structurally highest part of the present-day fold, which depending on the specific fold could be near its highest topographic expression, midway along the fold axis, or near to where it merges with an older, more developed fold $[13,82]$.

For the example of the River Dez incising across the Sardarabad Anticline, distance from fold core to location of river crossing, $\mathrm{C}-\mathrm{RC}=1.3 \mathrm{~km}$, as shown in Figure 6. For the example of the River Karun (Shuteyt) diverting around the Sardarabad Anticline, distance from fold core to location of river crossing, $\mathrm{C}-\mathrm{RC}=32.2 \mathrm{~km}$, also as shown in Figure 6. In this figure, the centre of the fold core is indicated by the black and yellow circle, the C-RC measurement along the fold axis to the River Dez crossing is indicated by the solid dark green line with two black arrowheads, and the C-RC measurement along the fold axis to the River Karun crossing is indicated by the dashed dark green line with two black arrowheads. In Figures 6-8: White = Quaternary Alluvium and Recent Deposits (c. 1 Ma-Present; generally unconsolidated alluvial sands, muds, gravels, and marls). Yellow (Bk) = Bakhtyari Formation (Middle Pliocene to Pleistocene, c. 3 Ma-1 Ma; well-consolidated conglomerates, sandstones, and mudstones). Dark orange $(\mathrm{Aj})=$ Agha Jari Formation (Middle Miocene to Middle Pliocene, c. 10 Ma-3 Ma; sandstones, marls, and mudstones). Light orange (Lbm) = Lahbari Member of Agha Jari Formation (Early to Middle Pliocene, c. 5.5 Ma-3 Ma; mudstones, marls, and sandstones) [69].

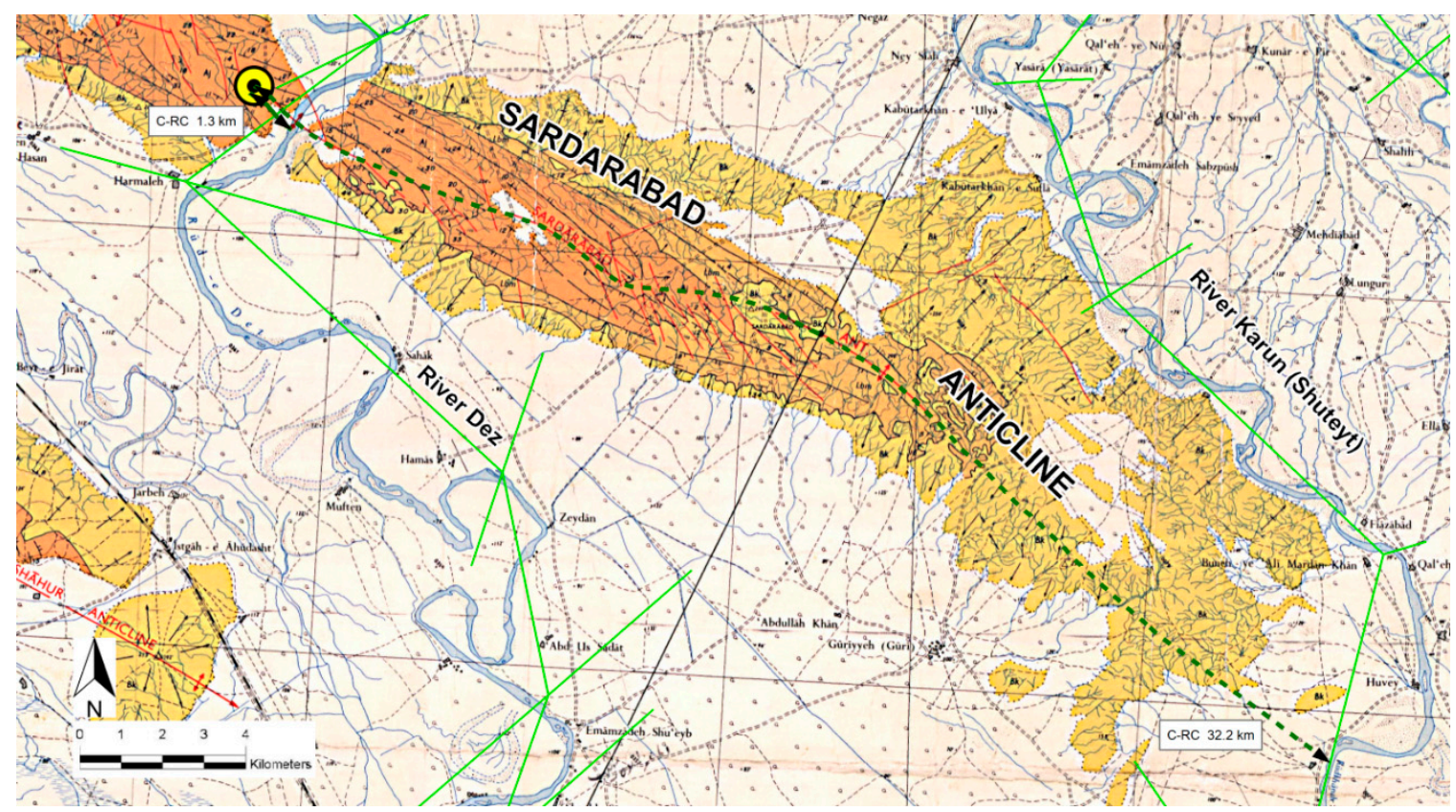

Figure 6. The measurement of C-RC (1:100,000 fine scale geological map (IOOC, 1969 [67]) of the rivers Dez and Karun (Shuteyt branch) interacting with the Sardarabad Anticline, centred on c. $31^{\circ} 54^{\prime} \mathrm{N}$ $48^{\circ} 42^{\prime} \mathrm{E}$ ). The axis of the anticline is shown as a red line with cross-bar, and straight-line river reaches are shown as thin green lines, with roughly orthogonal thin green lines demarcating successive reaches. 


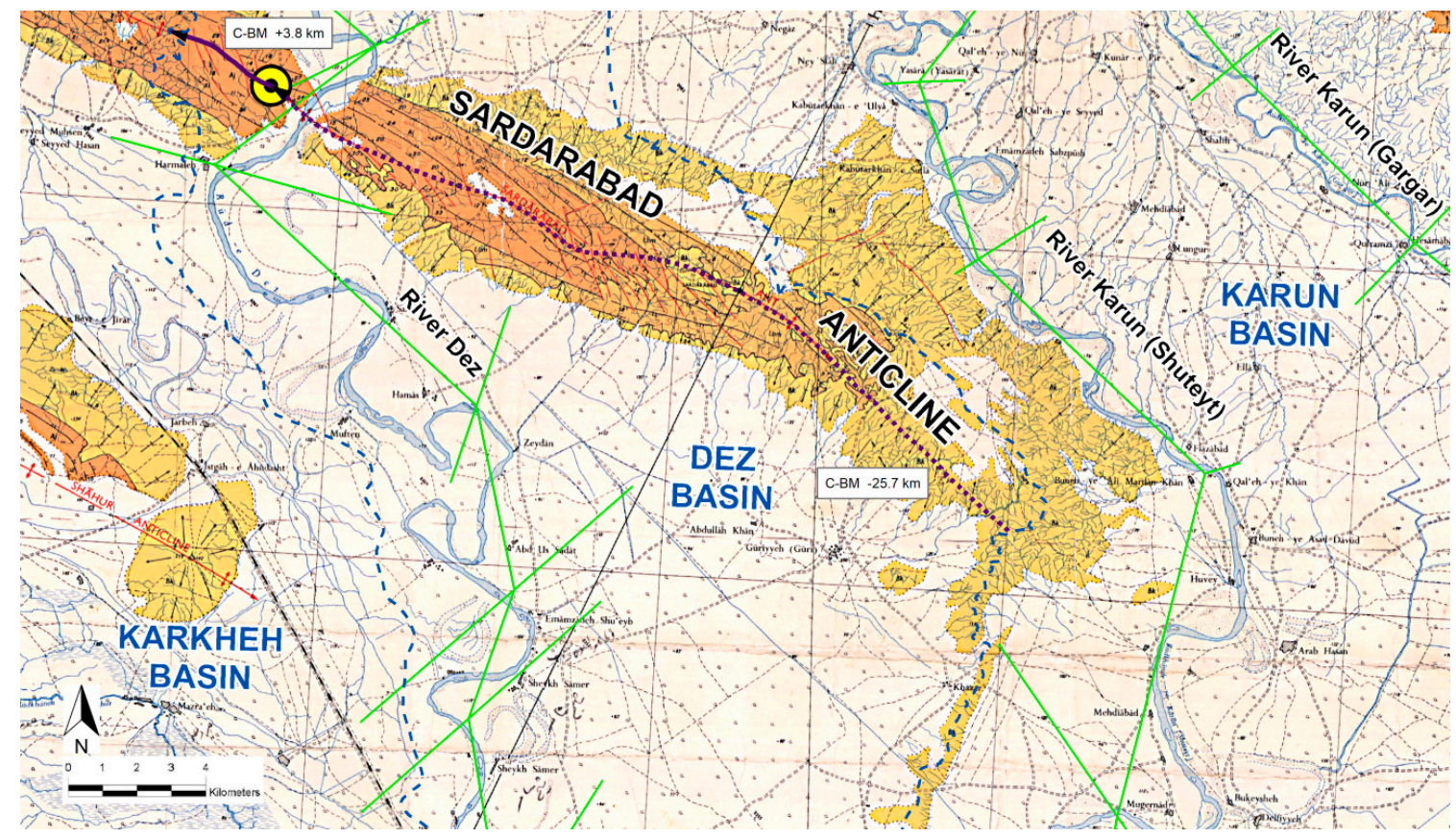

Figure 7. The measurement of C-BM (1:100,000 fine scale geological map (IOOC, 1969 [67]) of the rivers Dez and Karun (Shuteyt branch) interacting with the Sardarabad Anticline, centred on c. $31^{\circ} 53^{\prime} \mathrm{N}$ $48^{\circ} 43^{\prime} \mathrm{E}$ ). The axis of the anticline is shown as a red line with cross-bar, and straight-line river reaches are shown as thin green lines, with roughly orthogonal thin green lines demarcating successive reaches.

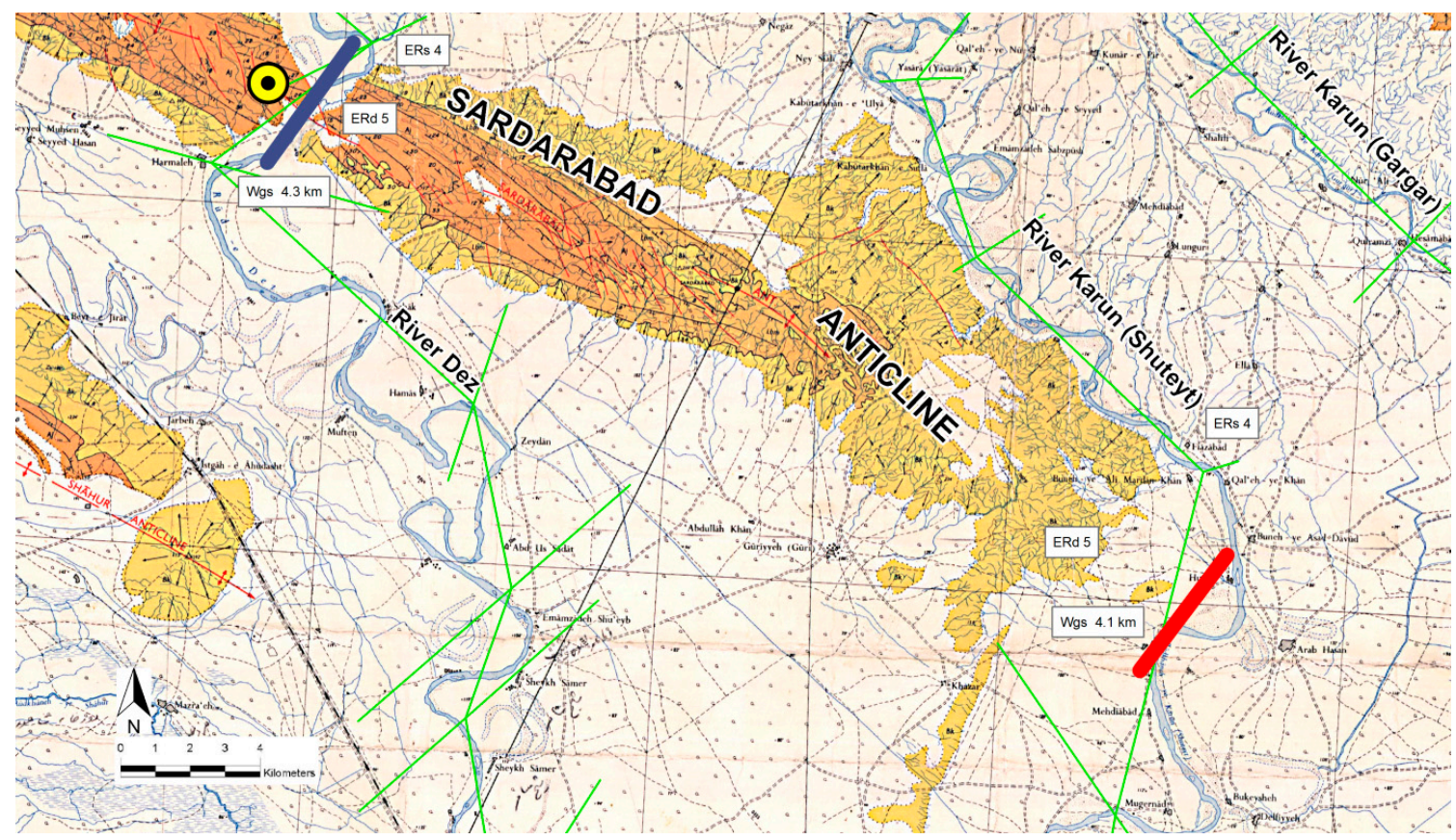

Figure 8. The measurement of Wgs, ERs and ERd (1:100,000 fine scale geological map (IOOC, 1969 [67]) of the rivers Dez and Karun (Shuteyt branch) interacting with the Sardarabad Anticline, centred on c. $31^{\circ} 53^{\prime} \mathrm{N} 48^{\circ} 43^{\prime} \mathrm{E}$ ). The axis of the anticline is shown as a red line with cross-bar, and straight-line river reaches are shown as thin green lines, with roughly orthogonal thin green lines demarcating successive reaches. 


\subsubsection{Distance From Fold Core to River Basin Margin}

Symbol: C-BM

Units: $\mathrm{km}$ (quoted to one decimal place, indicating positive or negative)

Measurement location: Along the fold axis, from the centre of the fold core to the nearest margin of the drainage basin of the river interacting with the fold

$\mathrm{C}-\mathrm{BM}$ is defined as the horizontal distance from the centre of the fold core, measured along the fold axis (and along the projection of the fold axis, where appropriate), to the nearest margin of the drainage basin of the river interacting with the fold [13]. The centre of the fold core is determined from fine scale geological maps, as described in Section 3.1.7. The drainage basin margins are demarcated from remote sensing images or topographical maps, by determining which river channels, wadis, lakes, streams and creeks are associated with each major river and by drawing a line midway between the extents of these. The zero point for measurements is at the centre of the fold core, with +ve values where the fold core is located within the drainage basin of the river interacting with the fold, and -ve values where the fold core is located outside of the drainage basin of the river interacting with the fold.

For the example of the River Dez incising across the Sardarabad Anticline, distance from fold core to river basin margin, $\mathrm{C}-\mathrm{BM}=+3.8 \mathrm{~km}$, as shown in Figure 7. For the example of the River Karun (Shuteyt) diverting around the Sardarabad Anticline, distance from fold core to river basin margin, $\mathrm{C}-\mathrm{BM}=-25.7 \mathrm{~km}$, also as shown in Figure 7. In this figure, the centre of the fold core is indicated by the black and yellow circle, drainage basin margins are indicated by dashed blue lines, the C-BM measurement along the fold axis to the nearest River Dez basin margin is indicated by the solid dark purple line with one black arrowhead, and the C-BM measurement along the fold axis to the nearest River Karun basin margin is indicated by the dashed dark purple line with one black arrowhead.

\subsubsection{Width of Geological Structure at Location of River Crossing}

Symbol: Wgs

Units: $\mathrm{km}$ (quoted to one decimal place)

Measurement location: Where river channel crosses the fold axis (or its projection), measured orthogonal to the fold axis (or its projection)

Wgs is defined as the maximum horizontal surface extent of the geological structure at the location where the river channel thalweg crosses the fold axis (or its projection), measured orthogonal to the fold axis (or its projection) [13]. For sub-surface folds with little or no surface topographic expression, known principally from oil and gas field locations and seismic surveys, this measurement is necessarily approximate. For river incision across a fold, the measurement is made orthogonal to the interpreted fold axis, between the margins of the mapped oil or gas field. For river diversion around a fold, the measurement is made orthogonal to the projection of the interpreted fold axis, between the projected margins of the nose of the mapped oil or gas field; a measurement which is highly subjective. For emerged folds with significant surface topographic expression, this measurement is much more certain. For river incision across a fold, the measurement is made orthogonal to the fold axis, between the surface extent of the fold limbs as determined from fine scale geological maps and fine scale topography. For river diversion around a fold, the measurement is made orthogonal to the projection of the fold axis, between the projected surface extent of the fold limbs of the nose of the fold; a measurement which is moderately subjective.

For the example of the River Dez incising across the Sardarabad Anticline, width of geological structure, Wgs $=4.3 \mathrm{~km}$, and for the River Karun (Shuteyt) diverting around the Sardarabad Anticline, Wgs $=4.1 \mathrm{~km}$, as shown on Figure 8. In this figure, the Wgs measurement for the River Dez crossing is indicated by the thick blue-grey line, and the Wgs measurement for the River Karun crossing is indicated by the thick red line. 
3.1.10. Estimate of Erosion Resistance of Surface Sediments/Rocks and Deeper Sediments/Rocks in Fold

Symbols: ERs (surface); ERd (deeper)

No units (estimate quoted on a relative scale from 1 to 8 )

Measurement location: Where river channel crosses the fold axis (or its projection)

This characteristic is defined as the resistance of sediments and rocks in a fold to river erosion, a parameter which can be difficult to quantify. It depends upon a variety of characteristics including structural geology, rock type, sediment type, strength of intact rock (especially rock compressive strength, rock tensile strength, and rock mass strength), resistance to weathering, jointing and fracturing (especially width, spacing, orientation, continuity, and infilling of joints), degree of movement of water through the rock mass, porosity, grain size, type and degree of cementation; as well as characteristics of the river, such as discharge, nature and frequency of floods, river sediment supply, suspended sediment concentration, and river bed roughness. Many of these characteristics are difficult to measure and their relative importance in determining the general erosion resistance of a fold is not fully known $[22,31,83-88]$.

Hence, for each case an estimate is made that is quoted as an integer on a scale, accompanied by a short description of the lithology or sedimentology, where known. The estimate of the erosion resistance of sediments and rocks is according to this scale:

1. Very low (Unlithified floodplain sediments-predominantly sands)

2. Low (Unlithified floodplain sediments-predominantly muds)

3. Low/Moderate (Mainly unlithified floodplain sediments-predominantly sands and silts; some quite poorly consolidated bedrock-such as Agha Jari Formation bedrock (quite poorly consolidated sandstones)-and other similar rocks-such as mudstones, evaporites and poorly consolidated limestones)

4. Moderate (Mainly quite poorly consolidated bedrock-such as Agha Jari Formation bedrock (quite poorly consolidated sandstones)-and other similar rocks-such as mudstones, evaporites and poorly consolidated limestones; some unlithified floodplain sediments)

5. Moderate/High (Mainly well consolidated bedrock-such as Bakhtyari Formation bedrock (very well consolidated conglomerates)-and other similar rocks-such as well consolidated limestones, marbles, sandstones and schists; some unlithified floodplain sediments and rocks of relatively low erosion resistance)

6. High (Mainly well consolidated bedrock-such as Bakhtyari Formation bedrock (very well consolidated conglomerates)-and other similar rocks-such as well consolidated limestones, marbles, sandstones and schists)

7. Very high (Very erosion resistant bedrock-basalts, gabbros, metasandstones and other very erosion resistant igneous and metamorphic rocks)

8. Extremely high (Extremely erosion resistant bedrock-quartzite, cherts, granites, andesites, gneisses and other extremely erosion resistant igneous and metamorphic rocks)

The position on this scale can be determined by careful interpretation of fine scale geological maps and remote sensing images, plus fieldwork and work on the properties of rocks and sediments, where available. The surface erosion resistance of the fold, ERs, is that of the surface lithology and sedimentology of the fold; especially that in the general vicinity of a river channel at the upstream location where the river first encounters the limb of the fold. The deeper erosion resistance of the fold, ERd, is that of the deeper lithology and sedimentology of the fold; especially that exposed in the general vicinity of an incising river channel at the location of the fold axis. With emerging folds, ERd may be unknown in some cases where the sub-surface geology is only poorly known.

For the example of the River Dez incising across the Sardarabad Anticline, ERs $=4$, ERd $=5$, and for the River Karun (Shuteyt) diverting around the Sardarabad Anticline, ERs $=4, \mathrm{ERd}=5$, as shown on Figure 8. For the location of the River Dez crossing, ERs = Moderate (surface of 
unlithified floodplain sediments, with outcrops of Bakhtyari Formation bedrock (well consolidated conglomerates) and Agha Jari Formation bedrock (quite poorly cemented sandstones) at SW, W and E edges of floodplain), and ERd = Moderate/High (Bakhtyari Formation bedrock (well consolidated conglomerates) overlying Agha Jari Formation bedrock (quite poorly consolidated sandstones)). For the location of the River Karun (Shuteyt) crossing, ERs = Moderate (surface of unlithified floodplain sediments, with outcrops of Bakhtyari Formation bedrock (well cemented conglomerates) at SW and W edges of floodplain), and ERd = Moderate/High (assuming Bakhtyari Formation bedrock overlying Agha Jari Formation bedrock).

\subsection{Measurement of Geomorphological Characteristics Nos. 11 to 13}

For determining these three characteristics for the rivers Karun and Dez, the precise hydrological and topographical surveys used were those of the Dez Ab Engineering Company from 1997-2000, supplemented by geomorphological fieldwork [13]. This data facilitated the measurement of channel water surface slopes. The superimposed database used included false-colour Landsat ETM+ satellite images (dated 2001), fine-scale geological maps, and CORONA satellite images (dated 1966 and 1968) which had been geo-referenced, orthorectified and enhanced in a unified database using ArcGIS ${ }^{\circledR}$ software $[85,89]$. This database facilitated the measurement of channel migrations with time, and facilitated easier measurement of characteristics associated with the fold core and fold axis. The data relating to vertical Earth surface movements were of various types, including radiocarbon dating of marine terrace sediments and Optically Stimulated Luminescence (OSL) dating of river terrace sediments, and enabled estimates of fold total uplift rate to be made $[13,56]$.

\subsubsection{Channel Water Surface Slope at Location of Fold Axis (or its Projection)}

Symbol: $s$

Units: $\mathrm{m} \mathrm{m}^{-1}$ (quoted in standard form to nearest $1 \times 10^{-7}$ )

Measurement location: Where river channel crosses the fold axis (or its projection), measured for the river reach crossing the fold axis (or its projection)

Channel water surface slope is determined by the equation, $s=H_{c} / L_{c}$ where $H_{c}$ is change in channel water surface elevation $(\mathrm{m})$ and $L_{c}$ is change in channel length $(\mathrm{m})$ [90]. Vertical accuracy should be at least of the order decimetres or better, ideally of the order of centimetres, or it will not be possible to discriminate the fine changes in slope associated with Earth surface movements, especially in lowland areas with very gentle slopes.

It is very difficult to determine sufficiently accurate channel water surface slopes from satellite remote sensing and fine scale geological maps, mainly due to their relatively poor vertical accuracy. Whilst Digital Elevation Models constructed from Shuttle Radar Topography Mission-30 m (SRTM-30m) data and Advanced Land Observing Satellite World 3D-30 m (AW3D30) data can be useful, they only have a vertical accuracy (Root Mean Square Errors) of about $5.7 \mathrm{~m}$ and $8.3 \mathrm{~m}$, respectively [91]. Greater accuracy may be obtainable from fine-scale topographical maps (especially maps of 1:25,000 scale and finer, with contour intervals of $5 \mathrm{~m}$ or less and frequent spot heights) [76], to determine river bank (and thus channel water surface) elevations. However, in general, more accurate additional data sources, such as precise hydrological or topographical surveys of the river, or hydrological and geomorphological fieldwork, will be needed to sufficient vertical accuracy. Even with precise surveys, there will be a variety of factors influencing water surface elevation measurements, such as local vegetation and obstructions, human modifications, levées, pools and riffles, eddies, and daily variations in discharge. These factors frequently induce appreciable errors, particularly in lowland areas with very gentle slopes. Thus, to reduce the influence of these errors, the channel water surface slope should be measured for the entirety of the river reach crossing the fold axis, or its projection. With all channel pattern types, the water surface of the main channel thalweg is used for the measurement.

For the example of the River Dez incising across the Sardarabad Anticline, channel water surface slope, $s=2.999 \times 10^{-4} \mathrm{~mm}^{-1}$, and for the River Karun (Shuteyt) diverting around the Sardarabad 
Anticline, $s=3.5 \times 10^{-6} \mathrm{~mm}^{-1}$. Precise hydrological and topographical surveys undertaken by the Dez Ab Engineering Company from 1997-2000 were used for these measurements.

\subsubsection{Average Channel Migration Rate}

Symbol: Rm

Units: $\mathrm{m} \mathrm{yr}^{-1}$ (quoted to three decimal places)

Measurement location: River reaches immediately upstream of fold, across the fold axis (or its projection), and immediately downstream of fold

$\mathrm{Rm}$, the average channel migration rate over a specified period, can be defined by the equation $\mathrm{Rm}=\left(\mathrm{A} / L_{c}\right) / \mathrm{yr}$ where $\mathrm{A}$ is total area of "migration polygons" drawn as shape files in a river reach between corresponding points of a river bank between remote sensing images of different dates $\left(\mathrm{m}^{2}\right)$; $L_{c}$ is channel length of reach $(\mathrm{m})$, and $\mathrm{yr}$ is number of years between the remote sensing images [92]. To determine average channel migration rate, it is necessary to have access to high-resolution remote sensing images separated by a time interval of c. 20-40 years and Geographic Information System (GIS) software (such as $\operatorname{ArcGIS}^{\circledR}$ ) to orthorectify and superimpose the two sets of remote sensing images. A time interval of c. 20-40 years should be long enough for significant channel migration to have taken place, though not so long that a channel may have migrated back to its original location. Where possible, one set of images should be high resolution aerial photographs or satellite images from the 1960 's or earlier, so that the time interval includes periods prior to major dam building and other major human impacts.

One of the river banks-the left bank when facing downstream - is manually digitised for each image set, the "migration polygons" created by their intersections are highlighted and saved as shape files, and the total area of these "migration polygons" for the river reach is calculated. For single-thread meandering and straight channel patterns, the left bank of the channel is used for the measurement. For multi-thread braided channel patterns, the left bank of the outermost braid channel is used for the measurement. For anastomosing or anabranching channel patterns, the left bank of the main active river channels is used, with any anabranches clearly separated by floodplain areas being considered as discrete channel-belts not included in the measurement. Using this value of A for the total area of the "migration" polygons, the channel length of the reach, $L_{c}$, and the mean time interval in years, the average channel migration rate, $\mathrm{Rm}$, can be calculated.

For the example of the River Dez incising across the Sardarabad Anticline, average channel migration rate, $\mathrm{Rm}=11,129 \mathrm{~m} \mathrm{yr}^{-1}$ (immediately upstream of fold); $1578 \mathrm{~m} \mathrm{yr}^{-1}$ (across fold axis); 4502 $\mathrm{m} \mathrm{yr}^{-1}$ (immediately downstream of fold), as shown in Figure 9. In this figure, false-colour Landsat ETM+ images (28 July 2001 and 4 August 2001) make up the background; thin red lines indicate the location of the river channel banks on CORONA satellite images (23 September 1966 and 5 February 1968); yellow "migration polygons" indicate left bank channel migration inwards (or to the right) over a mean time interval of 34.2 years; green "migration polygons" indicate left bank channel migration outwards (or to the left) over 34.2 years. 


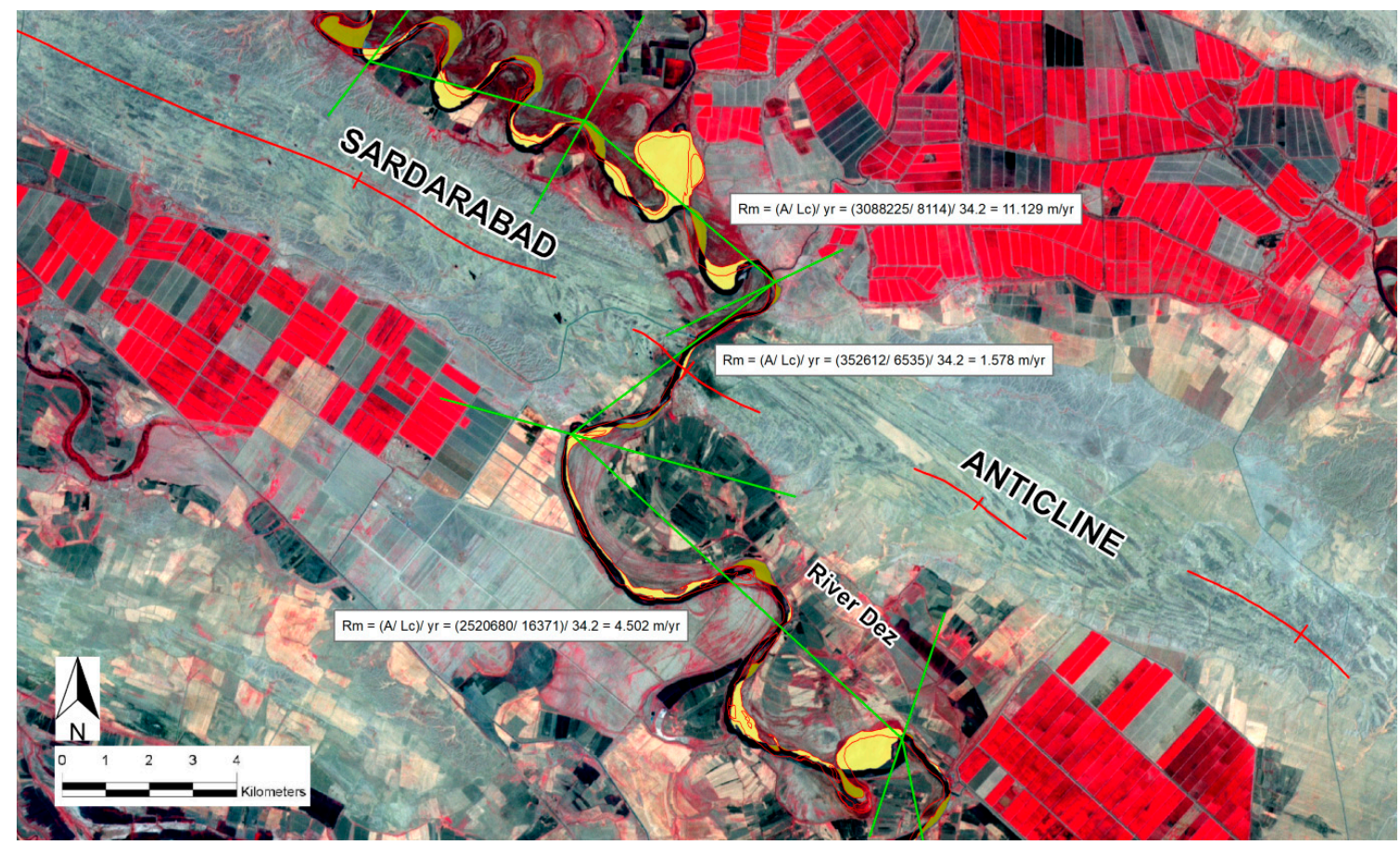

Figure 9. The measurement of Rm (False-colour Landsat image (2001) of the River Dez incising across the Sardarabad Anticline, centred on c. $31^{\circ} 57^{\prime} \mathrm{N} 48^{\circ} 36^{\prime} \mathrm{E}$ ). The axis of the anticline is shown as a red line with cross-bar, and straight-line river reaches are shown as thin green lines, with roughly orthogonal thin green lines demarcating successive reaches.

\subsubsection{Estimate of Fold Total Uplift Rate}

Symbol: TUR

No units (estimate quoted on a relative scale from 0 to 8 , roughly equivalent to ranges of rates of

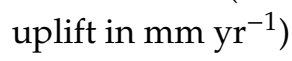

Measurement location: At, or near, the fold crest

The fold total uplift rate is defined as the rate at which a fold is rising above the surrounding region; that is, the single fold uplift rate less the sum of the regional subsidence rate and the sediment aggradation rate [29]. Generally, it is estimated or measured at, or near to, the fold crest because, in most cases, that is the part of the fold undergoing the greatest uplift relative to the surrounding region [93].

Fold total uplift rate cannot be determined solely from remote sensing images, remote sensing data, topographical maps, and geological maps. Other data sources are needed, which may be precision topographic survey (recurrent surveys over several decades to determine vertical surface movements) e.g., $[90,94]$, or precision GPS survey (recurrent measurements from GPS stations over several years to determine horizontal and vertical surface movements) e.g., $[60,95,96]$. Alternatively, the data sources may be the measurement and dating of uplifted geomorphic markers, especially marine terraces and river terraces e.g., $[51,56,59,97,98]$, the measurement and dating of archaeological structures, especially disused ancient canals e.g., [13,99], and the measurement and dating of structural geology, especially the development and erosion of fold growth strata e.g., [32,100]. Where such data is available for a fold, either by direct measurement or by careful interpretation, the estimated fold total uplift rate can be quoted as an integer on this relative scale:

1. Net subsidence (less than $0 \mathrm{~mm} \mathrm{yr}^{-1}$, the fold uplift rate is less than the sum of the regional subsidence rate and the sediment aggradation rate)

2. Very low (about $0-0.1 \mathrm{~mm} \mathrm{yr}^{-1}$ )

3. Low (about $0.1-0.2 \mathrm{~mm} \mathrm{yr}^{-1}$ ) 
4. Low/Moderate (about $0.2-0.5 \mathrm{~mm} \mathrm{yr}^{-1}$ )

5. Moderate (about $0.5-1.0 \mathrm{~mm} \mathrm{yr}^{-1}$ )

6. Moderate/High (about $1.0-4.0 \mathrm{~mm} \mathrm{yr}^{-1}$ )

7. High (about $4.0-8.0 \mathrm{~mm} \mathrm{yr}^{-1}$ )

8. Very high (about $8.0-12.0 \mathrm{~mm} \mathrm{yr}^{-1}$ )

9. Extremely high (more than $12.0 \mathrm{~mm} \mathrm{yr}^{-1}$ )

For the example of the River Dez incising across the Sardarabad Anticline, TUR = 3, and for the River Karun (Shuteyt) diverting around the Sardarabad Anticline, TUR $=3$. The TUR for the Sardarabad Anticline was estimated to be Low/Moderate (about $0.2-0.5 \mathrm{~mm} \mathrm{yr}^{-1}$ ) because OSL dating of river terrace sediments indicated uplift of the back-limb of the Sardarabad Anticline at a rate of $0.23-0.29 \mathrm{~mm} \mathrm{yr}^{-1}[13,20]$.

\section{Results for the Rivers Karun and Dez}

The results from applying the scheme to the River Karun and River Dez interacting with folds and emerging folds in lowland south-west Iran are given as a short description of the two rivers in Section 4.1, followed by tables of the results for the 13 geomorphological characteristics in Section 4.2. It is recommended that a similar format is used when applying the scheme to other major rivers in different parts of the world. The findings of Analysis of Variance (ANOVA) between river incision across a fold and river diversion around a fold, applied to the 13 geomorphological characteristics for the rivers Karun and Dez, are given in Section 4.3.

\subsection{Short Description of River}

River Karun (Iran)

Length: $890 \mathrm{~km}$

Drainage basin area: $45,230 \mathrm{~km}^{2}$

Mean annual water discharge: $575 \mathrm{~m}^{3} \mathrm{~s}^{-1}$ (at Ahvaz in the Khuzestan Plains)

Seasonality of discharge: Maximum in April (c. $850 \mathrm{~m}^{3} \mathrm{~s}^{-1}$, or more than $2,000 \mathrm{~m}^{3} \mathrm{~s}^{-1}$ prior to major dam construction); Minimum in October (c. $280 \mathrm{~m}^{3} \mathrm{~s}^{-1}$ ) (at Ahvaz in the Khuzestan Plains).

Major direct human impacts on river: Earliest major reservoir dam (constructed 1969-1976): Karun 1 or Shahid Abbaspour Dam at $32^{\circ} 03^{\prime} \mathrm{N} 49^{\circ} 36^{\prime} \mathrm{E}$. Major dam at furthest downstream location: Lower Gotvand Dam at $32^{\circ} 17^{\prime} \mathrm{N} 48^{\circ} 50^{\prime} \mathrm{E}$. Total of about seven large reservoir dams [101].

Short description of river course: Source in central/eastern Zagros on slopes of Zardeh Kuh, elevation c. $4200 \mathrm{~m}$-very winding, roughly west course through Zagros Mountains, often in accordance with general NW-SE structural grain and folding - generally west course across Zagros foothills-generally south course from Gotvand onwards across Upper Khuzestan Plains, with bifurcation at Shushtar into River Shuteyt (larger branch) to the west and River Gargar to the east, which re-unite at Band-e Qir in vicinity of confluence with River Dez - generally south-west course from Ahvaz across Lower Khuzestan Plains-joins Tigris-Euphrates-Karun delta at Khorramshahr and fans out in south-east direction into Persian Gulf $[13,35,54,102]$.

Short description of climate: Warm steppic climate. Central Zagros - various climates (mainly "sub-alpine", "mountain forest steppe" and "xerophilous oak woodland", annual precipitation c. 300 mm-1000 mm or more); snowy winter, mild \& rainy spring, dry summer/autumn; CSa, BSk, BSh (Köppen-Geiger Climate Classification)-Shahr-e Kord ( $32^{\circ} 20^{\prime} \mathrm{N} 50^{\circ} 52^{\prime} \mathrm{E}$, elevation $\left.2070 \mathrm{~m}\right)$ : mean daily Jan temp $-2{ }^{\circ} \mathrm{C}$, mean daily July temp $24^{\circ} \mathrm{C}$, mean annual precip $330 \mathrm{~mm}$. Zagros foothills and Upper Khuzestan Plains-"pistachio-almond scrubs" and "semi-arid steppe"; BSh-Izeh $\left(31^{\circ} 49^{\prime} \mathrm{N} 49^{\circ} 52^{\prime} \mathrm{E}\right.$, elevation $824 \mathrm{~m}$ ): mean daily Jan temp $8{ }^{\circ} \mathrm{C}$, mean daily July temp $33^{\circ} \mathrm{C}$, mean annual precip $383 \mathrm{~mm}$. Lower Khuzestan Plains-"arid desert steppe"; limited winter \& spring precipitation, long \& very hot summer drought; BWh-Ahvaz $\left(32^{\circ} 19^{\prime} \mathrm{N} 48^{\circ} 40^{\prime} \mathrm{E}\right.$, elevation $\left.21 \mathrm{~m}\right)$ : mean daily Jan temp $12^{\circ} \mathrm{C}$, mean daily July temp $37^{\circ} \mathrm{C}$, mean annual precip $209 \mathrm{~mm}[13,14,103-106]$. 
Short description of structural geology: Foreland basin tectonic setting. Convergence of Arabian Plate towards Eurasian Plate producing four NW-SE trending regional structural zones (from Zagros orogen in north-east to foreland basin in south-west): Sanandaj-Sirjan (or metamorphic) Zone (S-SZ); Imbricated Zone (IZ); Simple Folded Zone (SFZ) (including Dezful Embayment); Mesopotamian-Persian Gulf Foreland Basin (FB)-initially (Jurassic/Cretaceous onwards) oceanic subduction of Arabian Plate beneath Eurasian Plate, then transition (in Oligocene/Early Miocene) to continent-continent collision-ongoing plate convergence in approx. S-N direction at c. $16-22 \mathrm{~mm} \mathrm{yr}^{-1}$ (c. $18 \mathrm{~mm} \mathrm{yr}^{-1}$ in Dezful Embayment where River Karun flows), producing mainly NW-SE trending thrust faults and folds. Earth surface movements in Khuzestan Plains and Zagros mainly by aseismic folding \& faulting, and stable creep (probably due to lubricated décollements on evaporite layers)—earthquakes only account for small part of deformation. From Pliocene (c. $5 \mathrm{Ma}$ ) onwards deformation migrated away from orogen in north-east towards areas of thinner crust, producing successions of mainly NW-SE oriented thrust faults and associated NW-SE oriented detachment folds and fault bend folds. NW-SE oriented folds generally younger and less developed towards the south-west, dying out in vicinity of Zagros Deformation Front (ZDF) (NW-SE oriented line c. $30 \mathrm{~km}$ south-west of demarcation between Upper and Lower Khuzestan Plains). Folds are mainly asymmetric anticlines at or near ground surface-steeply dipping fore-limb to south-west and gently dipping back-limb to north-east. Typical fold lithostratigraphy in lowland south-west Iran: Quaternary deposits (c. 1 Ma-Present; unconsolidated alluvial sands, muds, gravels, and marls)-Middle Pliocene to Pleistocene Bakhtyari Formation (c. 3 Ma-1 Ma; well-consolidated conglomerates, sandstones, and mudstones)-Middle Miocene to Middle Pliocene Agha Jari Formation (c. $10 \mathrm{Ma}-3 \mathrm{Ma}$; sandstones, marls, and mudstones)-Middle Miocene Mishan Formation (c. $16 \mathrm{Ma}-10 \mathrm{Ma}$; marls, limestones, and sandstones)-Early Miocene Gachsaran Formation (c. $23 \mathrm{Ma}-16 \mathrm{Ma}$; anhydrite and salt, limestones, marls, and shales). South-west of ZDF in FB are very slowly propagating, mainly N-S oriented folds, uplifts and lineaments. Some structural lineaments throughout lowland south-west Iran, with prominent c. $110 \mathrm{~km}$ long "concealed fault/deep-seated lineament" oriented E-W at about $31^{\circ} 47^{\prime} \mathrm{N}$. Vertical Earth surface movements poorly known: Regional uplift to north-east of ZDF at c. $1 \mathrm{~mm} \mathrm{yr}^{-1}$ in central Zagros; regional subsidence to south-west of ZDF - fold uplift rates vary from about $0.01 / 0.024 \mathrm{~mm} \mathrm{yr}^{-1}$ in FB in Persian Gulf, to

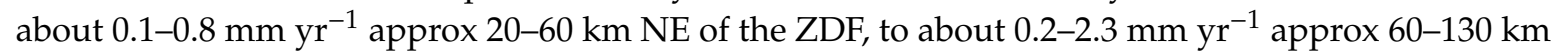
NE of the ZDF in Dezful Embayment [13,20,34,49,64,65,69,84,100,107-120].

River Dez (Iran)

Length: $515 \mathrm{~km}$

Drainage basin area: $23,250 \mathrm{~km}^{2}$

Mean annual water discharge: $230 \mathrm{~m}^{3} \mathrm{~s}^{-1}$

Seasonality of discharge: Similar to River Karun - Maximum in April; Minimum in October

Major direct human impacts on river: Earliest major reservoir dam (constructed 1959-1962): Dez Dam at $32^{\circ} 36^{\prime} \mathrm{N} 48^{\circ} 28^{\prime} \mathrm{E}$. Major dam at furthest downstream location: Dez Diversion Dam at $32^{\circ} 22^{\prime} \mathrm{N}$ $48^{\circ} 23^{\prime} \mathrm{E}$. Total of about five large reservoir dams [101].

Short description of river course: Source of Kamand River on Central Iranian Plateau, elevation c. 2,700 m-at confluence at Dorud becomes River Sehzar-roughly south-west course for both River Sehzar and its main tributary, River Bakhtyari, through the Zagros Mountains, mostly in discordance with general NW-SE structural grain and folding - generally south-west course across the Zagros foothills as River Dez-generally south course from Dezful onwards across Upper Khuzestan Plains, until confluence with River Karun at Band-e Qir [13,35,54].

Short description of climate: Very similar to River Karun - Warm steppic climate.

Short description of structural geology: Very similar to River Karun-Foreland basin tectonic setting. 


\subsection{Geomorphological Characteristics}

The geomorphology of the study area is complex and it was affected by tectonic processes over time. The results for the 13 geomorphological characteristics when applying the scheme to the River Karun and Dez interacting with folds in lowland south-west Iran are given in Table 2. This has been sub-divided into: Table 2 for the Turkalaki, Shushtar and Qal'eh Surkheh Anticlines and the River Karun; Table 3 for the Sardarabad, Qal'eh Surkheh and Kupal Anticlines and the River Karun and River Gargar; Table 4 for the Dezful Uplift and Sardarabad and Shahur Anticlines and the River Dez; Table 5 for the Ramin Oilfield, Ahvaz and Ab-e Teymur Oilfield Anticlines and the River Karun; and Table 6 for the Dorquain Oilfield Anticline and the River Karun.

\subsection{Statistical Analysis of Geomorphological Characteristics}

In tabulated form, the results for the geomorphological characteristics can be readily subjected to statistical analyses for investigating fold-river interactions. For the river Karun and Dez results given in Tables 2-6, Analysis of Variance (ANOVA) was applied between the categories of river incision across a fold and river diversion around a fold for each of the 13 geomorphological characteristics [13]. The ANOVA findings are summarised in Table 7, in which $F=$ Obtained $F$ value (mean sums of squares due to between-group differences/mean sums of squares due to within-group differences), $F$ crit $=$ Critical $F$ value needed to reject the null hypothesis, $p$-value $=$ Level of significance of $F$ value. In Table 7, bold text and yellow shading is used to highlight statistical significance, that is where $p$-value $\leq 0.05$ (equivalent to a $5 \%$ significance level or a $95 \%$ confidence level or better) $[74,121,122]$. 
Table 2. Results for 13 geomorphological characteristics in fold-river interactions for the Turkalaki, Shushtar and Qal'eh Surkheh Anticlines.

\begin{tabular}{|c|c|c|c|c|c|}
\hline & Geomorphological Characteristic & $\begin{array}{l}\text { Location of River } \\
\text { Reach or Depth of } \\
\text { Sediments/Rocks }\end{array}$ & $\begin{array}{l}\text { Turkalaki Anticline } \\
\text { River Karun } \\
\text { Incision Across Fold }\end{array}$ & $\begin{array}{l}\text { Shushtar Anticline } \\
\text { River Karun } \\
\text { Incision Across Fold }\end{array}$ & $\begin{array}{l}\text { Qal'eh Surkheh Ant. }^{\prime} \text { River Karun (Shuteyt) } \\
\text { Incision Across } \\
\text { Projection of Fold }\end{array}$ \\
\hline 1 & Channel width at location of the fold axis (or its projection) (m), $w$ & & 167.69 & 87.90 & 245.87 \\
\hline 2 & $\begin{array}{l}\text { Channel-belt width at location of the fold axis (or its projection) } \\
\qquad(\mathrm{km}), c b w\end{array}$ & & 0.424 & 0.652 & 2.698 \\
\hline 3 & Floodplain width at location of fold axis (or its projection) $(\mathrm{km}), f p w$ & & 0.935 & 1.173 & 5.638 \\
\hline \multirow{3}{*}{4} & \multirow{3}{*}{ Channel sinuosity (no units), Sc } & Upstream & 1.125 & 1.345 & 1.392 \\
\hline & & Across fold axis & 1.074 & 1.329 & 1.168 \\
\hline & & Downstream & 1.368 & 1.392 & 1.283 \\
\hline \multirow{3}{*}{5} & \multirow{3}{*}{ Braiding index (no units), $B I$} & Upstream & 1.0 & 1.7 & 2.0 \\
\hline & & Across fold axis & 1.1 & 1.0 & 2.0 \\
\hline & & Downstream & 2.4 & 2.0 & 3.1 \\
\hline \multirow{3}{*}{6} & \multirow{3}{*}{$\begin{array}{l}\text { General river course direction (compass bearing in degrees relative } \\
\text { to true north \& relative to the fold axis), RCD }\end{array}$} & Upstream & 280 & 180 & 250 \\
\hline & & Across fold axis & 205 & 205 & 205 \\
\hline & & Downstream & 170 & 250 & 225 \\
\hline 7 & Distance from fold core to location of river crossing ( $\mathrm{km}), \mathrm{C}-\mathrm{RC}$ & & 3.9 & 4.5 & 1.2 \\
\hline 8 & Distance from fold core to river basin margin $(\mathrm{km}), \mathrm{C}-\mathrm{BM}$ & & +3.9 & +8.6 & +3.6 \\
\hline 9 & Width of geological structure at location of river crossing $(\mathrm{km}), \mathrm{Wgs}$ & & 2.3 & 7.4 & 7.5 \\
\hline \multirow{2}{*}{10} & \multirow{2}{*}{$\begin{array}{l}\text { Estimate of erosion resistance of surface sediments/rocks and deeper } \\
\text { sediments/rocks in fold (no units, relative scale from } 1 \text { to } 8 \text { ) }\end{array}$} & ERs (surface) & 5 & 4 & 3 \\
\hline & & ERd (deeper) & 6 & 6 & 5 \\
\hline 11 & $\begin{array}{l}\text { Channel water surface slope at location of the fold axis (or its } \\
\text { projection) }\left(\mathrm{mm}^{-1}\right), s\end{array}$ & & $6.427 \times 10^{-4}$ & $4.018 \times 10^{-4}$ & $9.313 \times 10^{-4}$ \\
\hline \multirow{3}{*}{12} & \multirow{3}{*}{ Average channel migration rate $\left(\mathrm{m} \mathrm{yr}^{-1}\right), \mathrm{Rm}$} & Upstream & 2.228 & 8.728 & 3.540 \\
\hline & & Across fold axis & 1.096 & 1.468 & 4.430 \\
\hline & & Downstream & 3.123 & 3.540 & 18.072 \\
\hline 13 & $\begin{array}{l}\text { Estimate of fold total uplift rate (no units, relative scale from } 0 \text { to } 8 \text { ), } \\
\text { TUR }\end{array}$ & & 4 & 4 & 4 \\
\hline
\end{tabular}


Table 3. Results for 13 geomorphological characteristics in fold-river interactions for the Sardarabad, Qal'eh Surkheh and Kupal Anticlines.

\begin{tabular}{|c|c|c|c|c|c|}
\hline & Geomorphological Characteristic & $\begin{array}{l}\text { Location of River } \\
\text { Reach or Depth of } \\
\text { Sediments/Rocks }\end{array}$ & $\begin{array}{c}\text { Sardarabad Ant. } \\
\text { River Karun (Shuteyt) } \\
\text { Diversion around Nose } \\
\text { of Fold }\end{array}$ & $\begin{array}{l}\text { Qal'eh Surkheh Ant. } \\
\text { River Gargar } \\
\text { Incision Across } \\
\text { Projection of Fold }\end{array}$ & $\begin{array}{c}\text { Kupal Anticline } \\
\text { River Gargar } \\
\text { Incision Across Fold } \\
\text { (Near to Fold Nose) }\end{array}$ \\
\hline 1 & Channel width at location of the fold axis (or its projection) (m), $w$ & & 202.19 & 56.54 & 33.58 \\
\hline 2 & $\begin{array}{l}\text { Channel-belt width at location of the fold axis (or its projection) } \\
\qquad(\mathrm{km}), c b w\end{array}$ & & 2.051 & 0.314 & 0.154 \\
\hline 3 & Floodplain width at location of fold axis (or its projection) (km), fpw & & 17.603 & 0.415 & 2.347 \\
\hline \multirow{3}{*}{4} & \multirow{3}{*}{ Channel sinuosity (no units), $S c$} & Upstream & 1.798 & 1.066 & 2.629 \\
\hline & & Across fold axis & 1.647 & 1.164 & 1.259 \\
\hline & & Downstream & 1.682 & 1.243 & 1.061 \\
\hline \multirow{3}{*}{5} & \multirow{3}{*}{ Braiding index (no units), $B I$} & Upstream & 1.1 & 1.0 & 1.0 \\
\hline & & Across fold axis & 1.1 & 1.0 & 1.0 \\
\hline & & Downstream & 1.0 & 1.0 & 1.0 \\
\hline \multirow{3}{*}{6} & \multirow{3}{*}{$\begin{array}{l}\text { General river course direction (compass bearing in degrees relative } \\
\text { to true north \& relative to the fold axis), RCD }\end{array}$} & Upstream & 135 & 195 & 250 \\
\hline & & Across fold axis & 190 & 190 & 215 \\
\hline & & Downstream & 190 & 140 & 180 \\
\hline 7 & Distance from fold core to location of river crossing $(\mathrm{km}), \mathrm{C}-\mathrm{RC}$ & & 32.2 & 4.8 & 43.6 \\
\hline 8 & Distance from fold core to river basin margin (km), C-BM & & -25.7 & -3.6 & -16.0 \\
\hline 9 & Width of geological structure at location of river crossing $(\mathrm{km}), \mathrm{Wgs}$ & & 4.1 & 7.5 & 6.8 \\
\hline \multirow{2}{*}{10} & \multirow{2}{*}{$\begin{array}{l}\text { Estimate of erosion resistance of surface sediments/rocks and deeper } \\
\text { sediments/rocks in fold (no units, relative scale from } 1 \text { to } 8 \text { ) }\end{array}$} & ERs (surface) & 4 & 3 & 2 \\
\hline & & ERd (deeper) & 5 & 5 & 5 \\
\hline 11 & $\begin{array}{l}\text { Channel water surface slope at location of the fold axis (or its } \\
\text { projection) }\left(\mathrm{mm}^{-1}\right), s\end{array}$ & & $3.5 \times 10^{-6}$ & $2.8614 \times 10^{-3}$ & $1.278 \times 10^{-4}$ \\
\hline \multirow{3}{*}{12} & \multirow{3}{*}{ Average channel migration rate $\left(\mathrm{m} \mathrm{yr}^{-1}\right), \mathrm{Rm}$} & Upstream & 6.663 & 0.114 & 0.430 \\
\hline & & Across fold axis & 4.403 & 0.081 & 0.010 \\
\hline & & Downstream & 5.468 & 0 & 0.730 \\
\hline 13 & $\begin{array}{l}\text { Estimate of fold total uplift rate (no units, relative scale from } 0 \text { to } 8 \text { ), } \\
\text { TUR }\end{array}$ & & 3 & 4 & 4 \\
\hline
\end{tabular}


Table 4. Results for 13 geomorphological characteristics in fold-river interactions for the Dezful Uplift and the Sardarabad and Shahur Anticlines.

\begin{tabular}{|c|c|c|c|c|c|}
\hline & Geomorphological Characteristic & $\begin{array}{l}\text { Location of River Reach or } \\
\text { Depth of Sediments/Rocks }\end{array}$ & $\begin{array}{c}\text { Dezful Uplift } \\
\text { River Dez } \\
\text { Incision Across the Uplift }\end{array}$ & $\begin{array}{l}\text { Sardarabad Ant. } \\
\text { River Dez } \\
\text { Incision Across Fold }\end{array}$ & $\begin{array}{l}\text { Shahur Anticline } \\
\text { River Dez } \\
\text { Diversion Around } \\
\text { Nose of Fold }\end{array}$ \\
\hline 1 & $\begin{array}{l}\text { Channel width at location of the fold axis (or its } \\
\text { projection) (m), } w\end{array}$ & & 68.19 & 139.24 & 161.26 \\
\hline 2 & $\begin{array}{l}\text { Channel-belt width at location of the fold axis (or } \\
\text { its projection) }(\mathrm{km}), c b w^{1}\end{array}$ & & 0.365 & 0.833 & 7.297 \\
\hline 3 & $\begin{array}{l}\text { Floodplain width at location of fold axis (or its } \\
\text { projection) }(\mathrm{km}), f p w^{1}\end{array}$ & & 0.390 & 0.916 & 15.708 \\
\hline \multirow{3}{*}{4} & \multirow{3}{*}{ Channel sinuosity (no units), $S c$} & Upstream & 1.036 & 1.417 & 1.629 \\
\hline & & Across fold axis & 1.104 & 1.120 & 1.792 \\
\hline & & Downstream & 1.140 & 1.585 & 2.231 \\
\hline \multirow{3}{*}{5} & \multirow{3}{*}{ Braiding index (no units), $B I$} & Upstream & 1.0 & 1.0 & 1.0 \\
\hline & & Across fold axis & 1.9 & 1.2 & 1.0 \\
\hline & & Downstream & 6.5 & 1.2 & 1.0 \\
\hline \multirow{3}{*}{6} & \multirow{3}{*}{$\begin{array}{l}\text { General river course direction (compass bearing in } \\
\text { degrees relative to true north \& relative to the fold } \\
\text { axis), RCD }\end{array}$} & Upstream & 230 & 130 & 140 \\
\hline & & Across fold axis & 225 & 230 & 185 \\
\hline & & Downstream & 195 & 135 & 155 \\
\hline 7 & $\begin{array}{l}\text { Distance from fold core to location of river } \\
\text { crossing }(\mathrm{km}), \mathrm{C}-\mathrm{RC}\end{array}$ & & 15.1 & 1.3 & 22.8 \\
\hline 8 & $\begin{array}{l}\text { Distance from fold core to river basin margin }(\mathrm{km}) \text {, } \\
\text { C-BM }\end{array}$ & & +9.9 & +3.8 & -20.7 \\
\hline 9 & $\begin{array}{l}\text { Width of geological structure at location of river } \\
\text { crossing }(\mathrm{km}), \mathrm{Wgs}\end{array}$ & & 2.8 & 4.3 & 4.9 \\
\hline \multirow{2}{*}{10} & \multirow{2}{*}{$\begin{array}{l}\text { Estimate of erosion resistance of surface } \\
\text { sediments/rocks and deeper sediments/rocks in } \\
\text { fold (no units, relative scale from } 1 \text { to } 8 \text { ) }\end{array}$} & ERs (surface) & 4 & 4 & 4 \\
\hline & & ERd (deeper) & 6 & 5 & 5 \\
\hline 11 & $\begin{array}{l}\text { Channel water surface slope at location of the fold } \\
\text { axis (or its projection) }\left(\mathrm{mm}^{-1}\right), s\end{array}$ & & $1.9238 \times 10^{-3}$ & $2.999 \times 10^{-4}$ & $1.682 \times 10^{-4}$ \\
\hline \multirow{3}{*}{12} & \multirow{3}{*}{ Average channel migration rate $\left(\mathrm{m} \mathrm{yr}^{-1}\right), \mathrm{Rm}$} & Upstream & 0.566 & 11.129 & 5.538 \\
\hline & & Across fold axis & 0.534 & 1.578 & 2.841 \\
\hline & & Downstream & 5.852 & 4.502 & 1.890 \\
\hline 13 & $\begin{array}{l}\text { Estimate of fold total uplift rate (no units, relative } \\
\text { scale from } 0 \text { to } 8 \text { ), TUR }\end{array}$ & & 4 & 3 & 5 \\
\hline
\end{tabular}

${ }^{1}$ These two characteristics are new and indicate the authors' contribution in the text. 
Table 5. Results for 13 geomorphological characteristics in fold-river interactions for the Ramin Oilfield Anticline, Ahvaz Anticline and Ab-e Teymur Oilfield Anticline.

\begin{tabular}{|c|c|c|c|c|c|}
\hline & Geomorphological Characteristic & $\begin{array}{l}\text { Location of River } \\
\text { Reach or Depth of } \\
\text { Sediments/Rocks }\end{array}$ & $\begin{array}{l}\text { Ramin Oilfield Ant. } \\
\text { River Karun } \\
\text { Incision Across } \\
\text { Emerging Fold }\end{array}$ & $\begin{array}{l}\text { Ahvaz Anticline } \\
\text { River Karun } \\
\text { Incision Across Fold }\end{array}$ & $\begin{array}{c}\text { Ab-e Teymur Oilfield Ant. } \\
\text { River Karun } \\
\text { Incision Across } \\
\text { Emerging Fold }\end{array}$ \\
\hline 1 & $\begin{array}{l}\text { Channel width at location of the fold axis (or its } \\
\text { projection) }(\mathrm{m}), w\end{array}$ & & 325.07 & 320.27 & 191.18 \\
\hline 2 & $\begin{array}{l}\text { Channel-belt width at location of the fold axis (or its } \\
\text { projection) }(\mathrm{km}), c b w\end{array}$ & & 0.318 & 0.664 & 0.876 \\
\hline 3 & $\begin{array}{l}\text { Floodplain width at location of fold axis (or its projection) } \\
\qquad(\mathrm{km}), f p w\end{array}$ & & 17.335 & 0.668 & 43.438 \\
\hline \multirow{3}{*}{4} & \multirow{3}{*}{ Channel sinuosity (no units), $S c$} & Upstream & 1.702 & 2.167 & 3.283 \\
\hline & & Across fold axis & 1.010 & 1.047 & 1.858 \\
\hline & & Downstream & 2.468 & 1.078 & 1.176 \\
\hline \multirow{3}{*}{5} & \multirow{3}{*}{ Braiding index (no units), $B I$} & Upstream & 1.0 & 1.2 & 1.0 \\
\hline & & Across fold axis & 1.0 & 1.2 & 1.1 \\
\hline & & Downstream & 1.1 & 1.0 & 1.0 \\
\hline \multirow{3}{*}{6} & \multirow{3}{*}{$\begin{array}{l}\text { General river course direction (compass bearing in degrees } \\
\text { relative to true north \& relative to the fold axis), RCD }\end{array}$} & Upstream & 130 & 215 & 265 \\
\hline & & Across fold axis & 185 & 220 & 235 \\
\hline & & Downstream & 85 & 265 & 230 \\
\hline 7 & $\begin{array}{l}\text { Distance from fold core to location of river crossing }(\mathrm{km}) \text {, } \\
\text { C-RC }\end{array}$ & & 1.7 & 8.5 & 0.6 \\
\hline 8 & Distance from fold core to river basin margin $(\mathrm{km}), \mathrm{C}-\mathrm{BM}$ & & +18.0 & +22.0 & +15.0 \\
\hline 9 & $\begin{array}{l}\text { Width of geological structure at location of river crossing } \\
\qquad(\mathrm{km}), \mathrm{Wgs}\end{array}$ & & 4.0 & 2.3 & 4.4 \\
\hline \multirow{2}{*}{10} & \multirow{2}{*}{$\begin{array}{l}\text { Estimate of erosion resistance of surface sediments/rocks } \\
\text { and deeper sediments/rocks in fold (no units, relative scale } \\
\text { from } 1 \text { to } 8 \text { ) }\end{array}$} & ERs (surface) & 2 & 3 & 2 \\
\hline & & ERd (deeper) & - & 4 & 4 \\
\hline 11 & $\begin{array}{c}\text { Channel water surface slope at location of the fold axis (or } \\
\text { its projection) }\left(\mathrm{mm}^{-1}\right), s\end{array}$ & & $1.104 \times 10^{-4}$ & $6.136 \times 10^{-4}$ & $2.12 \times 10^{-5}$ \\
\hline \multirow{3}{*}{12} & \multirow{3}{*}{ Average channel migration rate $\left(\mathrm{m} \mathrm{yr}^{-1}\right), \mathrm{Rm}$} & Upstream & 4.907 & 0.781 & 2.198 \\
\hline & & Across fold axis & 0.712 & 1.008 & 2.833 \\
\hline & & Downstream & 2.711 & 3.224 & 0.982 \\
\hline 13 & $\begin{array}{l}\text { Estimate of fold total uplift rate (no units, relative scale } \\
\text { from } 0 \text { to } 8 \text { ), TUR }\end{array}$ & & 3 & 3 & 2 \\
\hline
\end{tabular}


Table 6. Results for 13 geomorphological characteristics in fold-river interactions for the Dorquain Oilfield Anticline.

\begin{tabular}{|c|c|c|c|}
\hline & Geomorphological Characteristic & $\begin{array}{l}\text { Location of River Reach or } \\
\text { Depth of Sediments/Rocks }\end{array}$ & $\begin{array}{c}\text { Dorquain Oilfield Ant. } \\
\text { River Karun } \\
\text { Diversion Around Nose of Emerging Fold }\end{array}$ \\
\hline 1 & Channel width at location of the fold axis (or its projection) $(\mathrm{m}), w$ & & 171.64 \\
\hline 2 & Channel-belt width at location of the fold axis (or its projection) (km), cbw & & 0.263 \\
\hline 3 & Floodplain width at location of fold axis (or its projection) (km), fpw & & 131.424 \\
\hline \multirow{3}{*}{4} & \multirow{3}{*}{ Channel sinuosity (no units), $S c$} & Upstream & 1.675 \\
\hline & & Across fold axis & 1.088 \\
\hline & & Downstream & 1.014 \\
\hline \multirow{3}{*}{5} & \multirow{3}{*}{ Braiding index (no units), $B I$} & Upstream & 1.0 \\
\hline & & Across fold axis & 1.0 \\
\hline & & Downstream & 1.0 \\
\hline \multirow{3}{*}{6} & \multirow{3}{*}{$\begin{array}{l}\text { General river course direction (compass bearing in degrees relative to true north \& } \\
\text { relative to the fold axis), RCD }\end{array}$} & Upstream & 190 \\
\hline & & Across fold axis & 230 \\
\hline & & Downstream & 245 \\
\hline 7 & Distance from fold core to location of river crossing $(\mathrm{km}), \mathrm{C}-\mathrm{RC}$ & & 26.5 \\
\hline 8 & Distance from fold core to river basin margin $(\mathrm{km}), \mathrm{C}-\mathrm{BM}$ & & +43.0 \\
\hline 9 & Width of geological structure at location of river crossing $(\mathrm{km}), \mathrm{Wgs}$ & & 9.2 \\
\hline \multirow{2}{*}{10} & \multirow{2}{*}{$\begin{array}{l}\text { Estimate of erosion resistance of surface sediments/rocks and deeper } \\
\text { sediments/rocks in fold (no units, relative scale from } 1 \text { to } 8 \text { ) }\end{array}$} & ERs (surface) & 2 \\
\hline & & ERd (deeper) & 4 \\
\hline 11 & Channel water surface slope at location of the fold axis (or its projection) $\left(\mathrm{mm}^{-1}\right), \mathrm{s}$ & & $3.56 \times 10^{-5}$ \\
\hline \multirow{3}{*}{12} & \multirow{3}{*}{ Average channel migration rate $\left(\mathrm{m} \mathrm{yr}^{-1}\right), \mathrm{Rm}$} & Upstream & 1.819 \\
\hline & & Across fold axis & 0.873 \\
\hline & & Downstream & 0.430 \\
\hline 13 & Estimate of fold total uplift rate (no units, relative scale from 0 to 8 ), TUR & & 1 \\
\hline
\end{tabular}


Table 7. Analysis of Variance (ANOVA) between river incision across a fold and river diversion around a fold, applied to 13 geomorphological characteristics in fold-river interactions for the rivers Karun and Dez in lowland south-west Iran.

\begin{tabular}{|c|c|c|c|}
\hline \multirow{2}{*}{$\begin{array}{c}\text { Geomorphological Characteristic } \\
\text { 1. Channel width at location of fold axis (or its projection) }(\mathrm{m}), w\end{array}$} & \multicolumn{3}{|c|}{$\begin{array}{l}\text { Analysis of Variance (ANOVA) Between Categories of River Incision } \\
\text { Across a Fold and River Diversion Around a Fold }\end{array}$} \\
\hline & $F=0.054$ & F crit $=4.844$ & $p$-value $=0.820$ \\
\hline 2. Channel-belt width at location of fold axis (or its projection) $(\mathrm{km}), c b w$ & $F=4.924$ & F crit $=4.844$ & $p$-value $=0.048$ \\
\hline 3. Floodplain width at location of fold axis (or its projection) $(\mathrm{km}), f p w$ & $F=5.488$ & F crit $=4.844$ & $p$-value $=0.039$ \\
\hline 4. Channel sinuosity (no units), Sc-Difference between river reach immediately upstream of fold and river reach across fold axis & $F=0.692$ & F crit $=4.844$ & $p$-value $=0.423$ \\
\hline 4. Channel sinuosity (no units), Sc-River reach across fold axis & $F=2.703$ & F crit $=4.844$ & $p$-value $=0.128$ \\
\hline 4. Channel sinuosity (no units), Sc-Difference between river reach across fold axis and river reach immediately downstream of fold & $F=0.010$ & $F$ crit $=4.844$ & $p$-value $=0.924$ \\
\hline 5. Braiding index (no units), BI-Difference between river reach immediately upstream of fold and river reach across fold axis & $F=0.055$ & F crit $=4.844$ & $p$-value $=0.818$ \\
\hline 5. Braiding index (no units), BI-River reach across fold axis & $F=0.795$ & F crit $=4.844$ & $p$-value $=0.392$ \\
\hline 5. Braiding index (no units), BI-Difference between river reach across fold axis and river reach immediately downstream of fold & $F=0.977$ & F crit $=4.844$ & $p$-value $=0.344$ \\
\hline $\begin{array}{l}\text { 6. General river course direction (compass bearing in degrees), RCD-Change in river course direction between river reach } \\
\text { immediately upstream of fold and river reach across fold axis }\end{array}$ & $F=0.208$ & F crit $=4.844$ & $p$-value $=0.657$ \\
\hline 6. General river course direction (compass bearing in degrees relative to true north), RCD-River reach across fold axis & $F=0.669$ & F crit $=4.844$ & $p$-value $=0.431$ \\
\hline 6. General river course direction (compass bearing in degrees relative to the fold axis), RCD - River reach across fold axis & $F=1.562$ & F crit $=4.844$ & $p$-value $=0.237$ \\
\hline $\begin{array}{l}\text { 6. General river course direction (compass bearing in degrees), RCD - Change in river course direction between river reach across } \\
\text { fold axis and river reach immediately downstream of fold }\end{array}$ & $F=2.234$ & F crit $=4.844$ & $p$-value $=0.163$ \\
\hline 7. Distance from fold core to location of river crossing $(\mathrm{km}), \mathrm{C}-\mathrm{RC}$ & $F=5.568$ & F crit $=4.844$ & $p$-value $=0.038$ \\
\hline 8. Distance from fold core to river basin margin $(\mathrm{km}), \mathrm{C}-\mathrm{BM}$ & $F=0.369$ & $F$ crit $=4.844$ & $p$-value $=0.556$ \\
\hline 9. Width of geological structure at location of river crossing $(\mathrm{km}), \mathrm{Wgs}$ & $F=0.568$ & F crit $=4.844$ & $p$-value $=0.467$ \\
\hline $\begin{array}{l}\text { 10. Estimate of erosion resistance of surface sediments/rocks and deeper sediments/rocks in fold (no units, relative scale from } 1 \text { to } \\
\text { 8), ERs (surface); ERd (deeper) }\end{array}$ & $\begin{array}{l}F=0.037 \\
F=0.800\end{array}$ & $\begin{array}{c}\text { ERs (surface) } \\
\text { F crit }=4.844 \\
\text { ERd (deeper } \\
\text { F crit }=4.965\end{array}$ & $\begin{array}{l}\text { e): } \\
p \text {-value }=0.851 \\
\text { r): } \\
p \text {-value }=0.392\end{array}$ \\
\hline 11. Channel water surface slope at location of fold axis (or its projection) $\left(\mathrm{mm}^{-1}\right), s$ & $F=1.765$ & F crit $=4.844$ & $p$-value $=0.211$ \\
\hline $\begin{array}{l}\text { 12. Average channel migration rate }\left(\mathrm{m} \mathrm{yr}^{-1}\right), \mathrm{Rm} \text { - Difference between river reach immediately upstream of fold and river reach } \\
\text { across fold axis }\end{array}$ & $F=0.003$ & F crit $=4.844$ & $p$-value $=0.958$ \\
\hline 12. Average channel migration rate $\left(\mathrm{m} \mathrm{yr}^{-1}\right), \mathrm{Rm}$ - River reach across fold axis & $F=1.983$ & $F$ crit $=4.844$ & $p$-value $=0.187$ \\
\hline $\begin{array}{l}\text { 12. Average channel migration rate }\left(\mathrm{m} \mathrm{yr}^{-1}\right), \mathrm{Rm} \text { - Difference between river reach across fold axis and river reach immediately } \\
\text { downstream of fold }\end{array}$ & $F=1.415$ & $F$ crit $=4.844$ & $p$-value $=0.259$ \\
\hline 13. Estimate of fold total uplift rate (no units, relative scale from 0 to 8 ), TUR & $F=0.508$ & $F$ crit $=4.844$ & $p$-value $=0.491$ \\
\hline
\end{tabular}




\section{Discussion}

The new scheme for investigating fold-river interactions was successfully applied to the major rivers Karun and Dez in lowland south-west Iran. It was found to be relatively easy to use in practice, with the notable exception of determining geomorphological characteristics Nos. 11, 12 and 13. The acquisition and interpretation of precise hydrological and topographical surveys of the rivers, the creation of a superimposed database of satellite images and fine scale geological maps, subdivision of the Karun and Dez into river reaches, creation of river "migration polygons", and acquisition of data relating to fold uplift rates, was time-consuming. Hence, especially since data for these last 3 geomorphological characteristics may not be available for all major rivers, they can be considered as supplementary characteristics.

\subsection{Significant Geomorphological Characteristics in Fold-River Interactions for the Rivers Karun and Dez in Lowland South-West Iran}

As is frequently the case in geomorphology, the measurements of the 13 geomorphological characteristics will vary according to where and how the observer take the measurements. Thus it is necessary to follow the directions given with the descriptions of each of the 13 characteristics, so that the measurements are standardised. This is especially the case with the subdivision into river reaches and the determination of the location of the fold core, where a greater degree of subjectivity is involved. Hence, it may be useful to include error estimates with the measurements of the geomorphological characteristics.

Considering this, and the natural variability and complexity of major rivers, it might be expected that none of the 13 geomorphological characteristics would show statistically significant differences between the categories of river incision across a fold and river diversion around a fold. Nevertheless, the Analysis of Variance (ANOVA) findings in Table 7 for the rivers Karun and Dez interacting with folds in lowland south-west Iran, show three geomorphological characteristics with statistically significant differences at the 95\% confidence level ( $p$-value $\leq 0.05$ ): channel-belt width at location of fold axis, floodplain width at location of fold axis, and distance from fold core to location of river crossing (geomorphological characteristics Nos. 2, 3 and 7).

Both channel-belt width and floodplain width at the location of the fold axis are significantly narrower for river incision across a fold compared with river diversion around a fold. In cases of river diversion, channel-belt width and floodplain width at the projection of the fold axis may have a wide range of values. By contrast, in cases of river incision, channel-belt width is always ( $100 \%$ of cases) less than $2.7 \mathrm{~km}$, and floodplain width is generally ( $80 \%$ of cases) less than $5.7 \mathrm{~km}$, at the location of the fold axis. A narrow channel-belt and a narrow floodplain at the location of the fold axis are indicative of a reduction in the lateral migration of the river at the fold axis to increase vertical incision of the river to keep pace with fold uplift. The general scenario is one of broader channel-belts and floodplains immediately upstream and downstream of the fold due to increased aggradation to maintain channel slopes across the fold, and narrow channel-belts and floodplains across the fold due to increased erosion and incision to keep pace with fold uplift [32,46,47]. A narrow channel-belt is present in all cases of river incision, probably because a channel-belt is a relatively small feature that typically develops over time intervals of several decades or more [123]. Indeed, an average channel-belt width of $2.7 \mathrm{~km}$ or less may be a threshold for the rivers Karun and Dez in the Khuzestan Plains that needs to be maintained if a major river is incise across a fold in the long-term [13]. By contrast, a narrow floodplain is not present in all cases or river incision, probably because a floodplain is a significantly larger feature that typically develops over time intervals of centuries [63]. Thus, in extensive, relatively flat areas, such as the Lower Khuzestan Plains, the streams and wetlands of the floodplain of a major river may extend far beyond the surface expression of a small fold and thus be unaffected by it.

It is not unexpected that the distance from the fold core to the location of the river crossing should discriminate between the two categories of fold-river interactions, since river incision occurs between the fold core and the fold nose, and river diversion occurs beyond the fold nose. Indeed, in all 
but one case of river incision the distance is less than $16 \mathrm{~km}$ (the exception of $43.6 \mathrm{~km}$ for the River Gargar incising across the Kupal Anticline is associated with pronounced human influences on the development of the River Gargar), whereas in all cases of river diversion the distance is greater than 22 kilometres. Interestingly, there is a strong tendency for a river to incise across the fold at locations near to that of the fold core $(8.5 \mathrm{~km}$ or less in $80 \%$ of cases $)$. Since the folds in the Khuzestan Plains are relatively young folds, this suggests that river incision across a fold at, or near to, the fold core is initiated at a very early stage in fold development, probably when the fold is initially emerging on the ground surface [13].

These findings can help to explain the seemingly paradoxical tendency of rivers to transect both young and old anticlines at or near to locations of their greatest structural and topographic relief. It can be considered that a fold initially emerges on the ground surface as a fold core, which in plan form may be an "oval", a "sausage", or another similar form, depending on the type of fold [33,82,122-125]. Where a major river initially encounters the fold as an emerging fold core, then the river may flow across the uplifting fold for sufficient time (at least several decades [123]) for the development of a narrow channel-belt; thus producing an incising river course across the fold in the vicinity of the fold core. As the fold grows vertically and laterally, depending on the size and nature of the river, the incising river course may be maintained and become "fixed" to produce a water gap in the fold in the vicinity of the subsequent structural culmination, or the river may be subsequently defeated to produce a wind gap and a diverted river course [124]. By contrast, where a major river initially encounters a fold as a larger, emerged fold, the river may not flow across the uplifting fold for sufficient time for a narrow channel-belt to develop, due to repeated channel migration in response to lateral fold growth; thus producing a river course diverting around the fold nose $[13,20]$.

Also, whilst other geomorphological characteristics are not discriminatory at the $95 \%$ confidence level, they do show some trends which support this model. River incision across a fold frequently has a general river course direction across the fold orthogonal to the fold axis, and river reaches across the fold axis have low channel sinuosities (generally $<1.4$ ), steep channel water surface slopes (generally $>1 \times 10^{-4} \mathrm{~mm}^{-1}$ ), and low average channel migration rates (generally $<2 \mathrm{~m} \mathrm{yr}^{-1}$ ). These trends might be related to the river initially encountering the fold as an emerging fold core, with reductions in lateral migration and increases in specific stream power as the river incises vertically in response to fold uplift. By contrast, river diversion around a fold frequently has a general river course direction upstream of the fold parallel to the fold axis and a course change of about $20^{\circ}-70^{\circ}$ to flow around the fold, and river reaches across the projection of the fold axis that have quite widely ranging channel sinuosities, gentle channel water surface slopes (generally $<1 \times 10^{-4} \mathrm{~mm}^{-1}$ ), and quite widely ranging average channel migration rates. These trends might be related to the river initially encountering the fold later in its development as a relatively large "obstacle", with a diverted river course, with frequent lateral migration in which there is only limited time for any increases in specific stream power to develop $[13,20]$.

\subsection{Significant Geomorphological Characteristics in Fold-River Interactions for Other Major Rivers}

These observed changes apply for the major rivers Karun and Dez in lowland south-west Iran. To investigate whether similar or different changes apply with other major rivers and other folds, the scheme should now be applied to a variety of major rivers across the globe. For other fold-river interactions, it is highly likely that different changes will be found, and that other characteristics of river and fold geomorphology may discriminate between river incision across a fold and river diversion around a fold.

For instance, for the rivers Karun and Dez interacting with active folds in lowland south-west Iran, it was found that channel-belt width was a key discriminative characteristic, whereas channel width and channel water surface slope were not. By contrast, an investigation of two side-by-side upland rivers crossing rapidly uplifting folds (rates of uplift exceeding $10 \mathrm{~mm} \mathrm{yr}^{-1}$ ) in the Himalayan foreland of central Nepal, found that both of the rivers exhibited a significant reduction in channel 
width across the zone of rock uplift $[51,53,126]$. The smaller Bakeya River became steeper across the zone of rapid uplift, whereas the larger Bagmati River showed no significant profile steepening across the same zone [51,52]. The research indicated that channel width acted as a key characteristic of river responses, and that if structural uplift should become sufficiently great, the channel width would reduce to less than a certain threshold width value to maintain an incising river course across a zone of uplift. Channel narrowing to enhance incision rates appeared to take precedence over other changes, such as channel steepening and reduced river profile concavity [27,52,53]; a scenario which has also been found with upland rivers elsewhere in the world. In central Taiwan, in response to increasing rates of differential uplift, upland rivers in studies were found to have progressively narrower channel widths until a channel width:depth ratio of about 10 was reached, after which they also steepened [58]. In southern New Zealand, surveys of small upland channels indicated that $1 \mathrm{~m}-2 \mathrm{~m}$ of uplift resulted in a five- to ten-fold narrowing of river channels [25]. Such findings enabled Amos and Burbank (2007) [25] to produce a conceptual model for a given river discharge, in which decreased channel width produced sufficient increased erosion to keep pace with uplift for small folds; whereas decreased channel width to a minimum value followed by subsequent channel steepening was needed to keep pace with uplift for larger folds [27]. Hence, it is highly likely that there are significant differences between fold-river interactions in upland and lowland river catchments, with the geomorphological characteristics of channel width and channel water surface slope probably being more significant with upland rivers. This should be investigated by extending the database for the scheme to a variety of upland rivers.

Also, it has been hypothesised that the seemingly paradoxical tendency for the rivers Karun and Dez in lowland south-west Iran to transect anticlines near to locations of their greatest structural and topographic relief, is primarily due to the nature and timing of the initial fold-river interactions $[13,20]$. However, there are other mechanisms that may account for this, which apply after the initial stages of fold development. It may arise by the drainage network being superimposed from above via a structurally conformable more easily eroded horizon [35,36]. It may arise in areas where the crust is deforming plastically in response to regional compression, as a consequence of focussed rock uplift in response to significant differences between net erosion along major rivers and the surrounding regions [127], or in response to significant unloading of the crust by river erosion that amplifies the background deformation to produce a doubly plunging anticline with a river valley at its centre [128,129]. Alternatively, with continued crustal shortening and thickening, it may arise with amplification of a regional slope that produces higher erosion rates in transverse catchments than in longitudinal catchments, and which creates a new organisation of the drainage system following the regional slope [130]. It is likely that there will be notable differences in the relative significance of the geomorphological characteristics with each of these mechanisms, which should be investigated by extending the database for the scheme to a wide variety of rivers across the globe.

\section{Conclusions}

This study has introduced and demonstrated a new scheme using remote sensing for investigating fold-river interactions for major rivers. This scheme involved a short description of the river, climate, and structural geology, and 13 geomorphological characteristics.

The scheme was successfully applied to the major rivers Karun and Dez in lowland south-west Iran, using widely available satellite imagery and fine scale geological maps. It was relatively easy to use in practice, though geomorphological characteristics Nos. 11, 12 and 13 involved additional data sources and additional processing, which was more difficult and time-consuming. Since the data needed for these last three geomorphological characteristics may not be available for all major rivers, they can be considered as supplementary characteristics.

For the major rivers Karun and Dez (mean annual water discharges $575 \mathrm{~m}^{3} \mathrm{~s}^{-1}$ and $230 \mathrm{~m}^{3} \mathrm{~s}^{-1}$, respectively) interacting with folds in lowland south-west Iran, it was found that geomorphological characteristics Nos. 2, 3 and 7 (channel-belt width, floodplain width, and distance from fold core to 
location of river crossing) had statistically significant differences ( $p$-value $\leq 0.05$ ) between the categories of river incision across a fold and river diversion around a fold. These findings suggest that the nature and timing of initial fold-river interactions is important in determining whether a river incises across a fold or diverts around it, and that the formation and maintenance of a narrow channel-belt and a narrow floodplain are necessary for a major river to incise across a fold, with this incision frequently being in the vicinity of the fold core and subsequent structural culmination.

The scenario in the foreland basin tectonic setting of lowland south-west Iran involves major rivers (of which the Karun and Dez are the largest) interacting with relatively young, emerging, thrust-related folds, with gradual earth surface movements predominating due to lubricated décollements on evaporite layers. In this scenario, the new scheme was found to be useful and identified channel-belt width, floodplain width, and distance from fold core to river crossing as important characteristics in the interactions between the major rivers and the folds. The scheme should now be applied to a wide variety of major rivers across the globe, to determine its usefulness in other scenarios and improve our knowledge of fold-river interactions. By comparing the same parameters for different major rivers, a better understanding of fold-river interactions should be achieved.

Author Contributions: Conceptualization, K.P.W.; methodology, K.P.W., D.R.P., S.P.; software, K.P.W., S.P.; validation, S.P., K.P.W.; formal analysis, K.P.W.; investigation, K.P.W., S.P.; resources, K.P.W., D.R.P., S.P.; data curation, K.P.W., S.P., D.R.P.; writing—original draft preparation, K.P.W.; writing—review and editing, S.P., D.R.P.; visualization, S.P., D.R.P., K.P.W.; supervision, D.R.P., S.P.; project administration, K.P.W., D.R.P., S.P.; funding acquisition, S.P., K.P.W., D.R.P.

Funding: This work was partly funded by the British Council, British Institute of Persian Studies, British Society for Geomorphology, Quaternary Research Association, Sir Philip Reckitt Educational Trust, and University of Hull. This research also received funds for publication from the start up funds, Faculty of Geosciences and Environmental Engineering (FGEE), Southwest Jiaotong University (SWJTU), China, and from the Energy and Environment Institute, University of Hull, UK.

Acknowledgments: Thanks are expressed to the funding organisations for generous support, to the Geological Survey of Iran and the Khuzestan Water and Power Authority for collaborative fieldwork in south-west Iran, and to Mark Bateman and Morteza Fattahi at the SCIDR luminescence laboratory in Sheffield for associated OSL dating. Analysis of remote sensing images and maps of south-west Iran was undertaken with the kind assistance of the Geological Survey of Belgium.

Conflicts of Interest: The authors declare no conflict of interest.

Submission Declaration and Verification: This research work has neither been published previously nor under consideration for publication elsewhere.

Data Availability: All data are available upon request.

\section{References}

1. Jones, S.J.; Frostick, L.E.; Astin, T.R. Climatic and tectonic controls on fluvial incision and aggradation in the Spanish Pyrenees. J. Geol. Soc. Lond. 1999, 156, 761-769. [CrossRef]

2. Blum, M.D.; Törnqvist, T.E. Fluvial responses to climate and sea-level change: A review and look forward. Sedimentology 2000, 47, 2-48. [CrossRef]

3. Schumm, S.A.; Dumont, J.F.; Holbrook, J.M. Active Tectonics and Alluvial Rivers; Cambridge University Press: Cambridge, UK, 2000; p. 276.

4. Lang, A.; Bork, H.-R.; Mäckel, R.; Preston, N.; Wunderlich, J.; Dikau, R. Changes in sediment flux and storage within a fluvial system: Some examples from the Rhine catchment. Hydrol. Process. 2003, 17, 321-334. [CrossRef]

5. Vandenberghe, J. Climate forcing of fluvial system development: An evolution of ideas. Quat. Sci. Rev. 2003, 22, 2053-2060. [CrossRef]

6. Dollar, E.S.J. Fluvial geomorphology. Prog. Phys. Geogr. 2004, 28, 405-450. [CrossRef]

7. Brierley, G.J.; Fryirs, K.A. Geomorphology and River Management: Applications of the River Styles Framework; Blackwell Publishing: Malden, MA, USA, 2005; p. 398.

8. Schumm, S.A. River Variability and Complexity; Cambridge University Press: Cambridge, UK, 2005; p. 220. 
9. Van de Wiel, M.J.; Coulthard, T.J. Self-organized criticality in river basins: Challenging sedimentary records of environmental change. Geology 2010, 38, 87-90. [CrossRef]

10. Meybeck, M.; Friedrich, G.; Thomas, R.; Chapman, D. Chapter 6-Rivers. In Water Quality Assessments-A Guide to Use of Biota, Sediments and Water in Environmental Monitoring, 2nd ed.; Chapman, D., Ed.; Spon on behalf of WHO: London, UK, 1996; p. 79.

11. Nittrouer, J.A.; Shaw, J.; Lamb, M.P.; Mohrig, D. Spatial and temporal trends for water-flow velocity and bed-material transport in the lower Mississippi River. Bull. Geol. Soc. Am. 2012, 124, 400-414. [CrossRef]

12. Blum, M.; Martin, J.; Milliken, K.; Garvin, M. Paleovalley systems: Insights from Quaternary analogs and experiments. Earth-Sci. Rev. 2013, 116, 128-169. [CrossRef]

13. Woodbridge, K.P. The Influence of Earth Surface Movements and Human Activities on the River Karun in Lowland South-West Iran. Unpublished Ph.D. Thesis, University of Hull, Hull, UK, 2013; p. 324. Available online: https://hydra.hull.ac.uk/resources/hull:8454 (accessed on 9 July 2019).

14. Potts, D.T. The Archaeology of Elam: Formation and Transformation of an Ancient Iranian State; Cambridge University Press: Cambridge, UK, 1999; p. 490.

15. Badripour, H.; Suttie, J.M.; Reynolds, S.G. Country Pasture/Forage Resource Profiles: Islamic Republic of Iran. 2006. Available online: www.fao.org/ag/AGP/agpc/doc/Counprof/Iran/Iran.htm (accessed on 9 July 2019).

16. Peng, J.; Chen, S.; Dong, P. Temporal variation of sediment load in the Yellow River basin, China, and its impacts on the lower reaches and the river delta. Catena 2010, 83, 135-147. [CrossRef]

17. Shanley, K.W.; McCabe, P.J. Alluvial architecture in a sequence stratigraphic framework: A case study from the Upper Cretaceous of southern Utah, USA. In The Geological Modelling of Hydrocarbon Reservoirs and Outcrop Analogues; Flint, S.S., Bryant, I.D., Eds.; IAS Special Publication No. 15; Blackwell: Oxford, UK, 1993; pp. 21-55.

18. Li, C.; Wang, P.; Fan, D.; Yang, S. Characteristics and formation of Late Quaternary incised-valley-fill sequences in sediment-rich deltas and estuaries: Case studies from China. In Incised Valleys in Time and Space; Dalrymple, R.W., Leckie, D.A., Tillman, R.W., Eds.; SEPM Special Publication No. 85; SEPM: Tulsa, OK, USA, 2006; pp. 141-160.

19. Wilkinson, T.J. Archaeological Landscapes of the Near East; University of Arizona Press: Tucson, AZ, USA, 2003; p. 261.

20. Woodbridge, K.P.; Parsons, D.R.; Heyvaert, V.M.A.; Walstra, J.; Frostick, L.E. Characteristics of direct human impacts on the rivers Karun and Dez in lowland south-west Iran and their interactions with Earth surface movements. Quat. Int. 2016, 392, 315-334. [CrossRef]

21. Alizadeh, A.; Kouchoukos, N.; Wilkinson, T.J.; Bauer, A.M.; Mashkour, M. Human-Environment Interactions on the Upper Khuzestan Plains, Southwest Iran. Recent Investigations. Paléorient 2004, 30, 69-88. [CrossRef]

22. Burbank, D.; Meigs, A.; Brozović, N. Interactions of growing folds and coeval depositional systems. Basin Res. 1996, 8, 199-223. [CrossRef]

23. DeCelles, P.G.; Giles, K.A. Foreland basin systems. Basin Res. 1996, 8, 105-123. [CrossRef]

24. Humphrey, N.F.; Konrad, S.K. River incision or diversion in response to bedrock uplift. Geology 2000, 28, 43-46. [CrossRef]

25. Amos, C.A.; Burbank, D.W. Channel width response to differential uplift. J. Geophys. Res. 2007, 112, F02010. [CrossRef]

26. Douglass, J.; Meek, N.; Dorn, R.I.; Schmeeckle, M.W. A criteria-based methodology for determining the mechanism of transverse drainage development, with application to the southwestern United States. Bull. Geol. Soc. Am. 2009, 121, 586-598. [CrossRef]

27. Burbank, D.W.; Anderson, R.S. Tectonic Geomorphology, 2nd ed.; Wiley-Blackwell: Chichester, UK, 2012 ; p. 454.

28. Bufe, A.; Paola, C.; Burbank, D.W. Fluvial bevelling of topography controlled by lateral channel mobility and uplift rate. Nat. Geosci. 2016, 9, 706-710. [CrossRef]

29. Doglioni, C.; Prosser, G. Fold uplift versus regional subsidence and sedimentation rate. Mar. Pet. Geol. 1997, 14, 179-190. [CrossRef]

30. Sklar, L.S.; Dietrich, W.E. A mechanistic model for river incision into bedrock by saltating bedload. Water Resour. Res. 2014, 40, W06301. [CrossRef]

31. Brocklehurst, S.H. Tectonics and geomorphology. Prog. Phys. Geogr. 2010, 34, 357-383. [CrossRef]

32. Burbank, D.W.; Beck, R.A. Rapid, long-term rates of denudation. Geology 1991, 19, 1169-1172. [CrossRef] 
33. Burberry, C.M.; Cosgrove, J.W.; Liu, J.G. Spatial Arrangement of Fold Types in the Zagros Simply Folded Belt, Iran, Indicated by Landform Morphology and Drainage Pattern Characteristics. J. Maps 2008, 4, 417-430. [CrossRef]

34. Burberry, C.M.; Cosgrove, J.W.; Liu, J.-G. A study of fold characteristics and deformation style using the evolution of the land surface: Zagros Simply Folded Belt, Iran. In Tectonic and Stratigraphic Evolution of Zagros and Makran during the Mesozoic-Cenozoic; Leturmy, P., Robin, C., Eds.; Special Publication No. 330; Geological Society of London: Bath, UK, 2010; pp. 139-154.

35. Oberlander, T. The Zagros Streams: A New Interpretation of Transverse Drainage in an Orogenic Zone; Syracuse University Press: Syracuse, NY, USA, 1965; p. 168.

36. Oberlander, T.M. Origin of drainage transverse to structures in orogens. In Tectonic Geomorphology, Proceedings of the 15th Annual Binghamton Geomorphology Symposium, September 1984; Morisawa, M., Hack, J.T., Eds.; Allen and Unwin: Boston, MA, USA, 1985; pp. 155-182.

37. Alvarez, W. Drainage on evolving fold-thrust belts: A study of transverse canyons in the Apennines. Basin Res. 1999, 11, 267-284. [CrossRef]

38. Jackson, J.; Norris, R.; Youngson, J. The structural evolution of active fault and fold systems in central Otago, New Zealand: Evidence revealed by drainage patterns. J. Struct. Geol. 1996, 18, 217-234. [CrossRef]

39. Ramsey, L.A.; Walker, R.T.; Jackson, J. Fold evolution and drainage development in the Zagros mountains of Fars province, SE Iran. Basin Res. 2008, 20, 23-48. [CrossRef]

40. Downs, P.W.; Gregory, K.J. River Channel Management: Towards Sustainable Catchment Hydrosystems; Routledge: London, UK, 2004; p. 395.

41. Schumm, S.A. To Interpret the Earth: Ten Ways to Be Wrong; Cambridge University Press: Cambridge, UK, 1991; p. 133.

42. Knighton, D. Fluvial Forms and Processes: A New Perspective; Arnold: London, UK, 1998; p. 383.

43. Brunsden, D.; Thornes, J.B. Landscape sensitivity and change. Transactions of the Institute of British Geographers. New Ser. 1979, 4, 463-484.

44. Van de Wiel, M.J.; Coulthard, T.J.; Macklin, M.G.; Lewin, J. Modelling the response of river systems to environmental change: Progress, problems and prospects for palaeo-environmental reconstructions. Earth-Sci. Rev. 2011, 104, 167-185. [CrossRef]

45. Coulthard, T.J.; Van de Wiel, M.J. Quantifying fluvial non linearity and finding self organised criticality? Insights from simulations of river basin evolution. Geomorphology 2007, 91, 216-235. [CrossRef]

46. Holbrook, J.; Schumm, S.A. Geomorphic and sedimentary response of rivers to tectonic deformation: A brief review and critique of a tool for recognizing subtle epeirogenic deformation in modern and ancient settings. Tectonophysics 1999, 305, 287-306. [CrossRef]

47. Douglass, J.; Schmeeckle, M. Analogue modeling of transverse drainage mechanisms. Geomorphology 2007, 84, 22-43. [CrossRef]

48. Brozović, N.; Burbank, D.W.; Fielding, E.; Meigs, A.J. The spatial and temporal topographic evolution of Wheeler Ridge, California: New insights from elevation data. Geol. Soc. Am. Abstr. Programs 1995, 27, 396.

49. Jackson, J.; Haines, J.; Holt, W. The accommodation of Arabia-Eurasia plate convergence in Iran. J. Geophys. Res. 1995, 100, 15205-15219. [CrossRef]

50. Jorgensen, D.W. Adjustment of Alluvial River Morphology and Process to Localized Active Tectonics. Unpublished Ph.D. Thesis, Colorado State University, Fort Collins, CO, USA, 1990; p. 240.

51. Lavé, J.; Avouac, J.P. Active folding of fluvial terraces across the Siwaliks Hills, Himalayas of central Nepal. J. Geophys. Res. 2000, 105, 5735-5770. [CrossRef]

52. Lavé, J.; Avouac, J.P. Fluvial incision and tectonic uplift across the Himalayas of central Nepal. J. Geophys. Res. 2001, 106, 26561-26591. [CrossRef]

53. Kirby, E.; Whipple, K. Quantifying differential rock-uplift rates via stream profile analysis. Geology 2001, 29, 415-418. [CrossRef]

54. Kirkby, M.J. Appendix 1. Land and Water Resources of the Deh Luran and Khuzistan Plains. In Studies in the Archaeological History of the Deh Luran Plain. The Excavation of Chagha Sefid; Memoirs of the Museum of Anthropology; Hole, F., Ed.; No. 9; University of Michigan: Ann Arbor, MI, USA, 1977; pp. 251-288.

55. Zámolyi, A.; Székely, B.; Draganits, E.; Timár, G. Neotectonic control on river sinuosity at the western margin of the Little Hungarian Plain. Geomorphology 2010, 122, 231-243. [CrossRef] 
56. Woodbridge, K.P.; Frostick, L.E. OSL dating of Karun river terrace sediments and rates of tectonic uplift in lowland south-west Iran. Quat. Newsl. 2014, 134, 44-52.

57. Yeromenko, V.Y.; Ivanov, V.P. Study of river meandering in the search for tectonic structures (as exemplified by the Middle Dniester Region). Sov. Hydrol. Sel. Pap. 1977, 16, 9-14.

58. Yanites, B.J.; Tucker, G.E.; Mueller, K.J.; Chen, Y.-G.; Wilcox, T.; Huang, S.-Y.; Shi, K.-W. Incision and channel morphology across active structures along the Peikang River, central Taiwan: Implications for the importance of channel width. Bull. Geol. Soc. Am. 2010, 122, 1192-1208. [CrossRef]

59. Oveisi, B.; Lavé, J.; Van der Beek, P.; Carcaillet, J.; Benedetti, L.; Aubourg, C. Thick-and thin-skinned deformation rates in the central Zagros simple folded zone (Iran) indicated by displacement of geomorphic surfaces. Geophys. J. Int. 2008, 176, 627-654. [CrossRef]

60. Ching, K.-E.; Hsieh, M.-E.; Johnson, K.M.; Chen, K.-H.; Rau, R.-J.; Yang, M. Modern vertical deformation rates and mountain building in Taiwan from precise leveling and continuous GPS observations, 2000-2008. J. Geophys. Res. 2011, 116, B08406. [CrossRef]

61. Pirasteh, S.; Woodbridge, K.; Rizvi, S.M.A. Geo-information technology (GiT) and tectonic signatures: The River Karun \& Dez, Zagros Orogen in south-west Iran. Int. J. Remote Sens. 2009, 30, 389-403.

62. Allen, M.B.; Talebian, M. Structural variation along the Zagros and the nature of the Dezful Embayment. Geol. Mag. 2011, 148, 911-924. [CrossRef]

63. Heyvaert, V.M.A.; Verkinderen, P.; Walstra, J. Geoarchaeological Research in Lower Khuzestan: State of the Art. In Susa and Elam. Archaeological, Philological, Historical and Geographical Perspectives, Proceedings of the International Congress Held at Ghent University, Ghent, Belgium, 14-17 December 2009; Volume 58 of Mémoires de la Délégation en Perse Series; De Graef, K., Tavernier, J., Eds.; Brill Academic Publishers: Leiden, The Netherlands, 2013; pp. 493-534.

64. National Iranian Oil Company (NIOC). Geological Map of Iran Sheet No. 4 South-West Iran, 1: 1,000,000 Scale. (Including South-West Iran and Northern Persian Gulf Oil Fields); NIOC: Tehran, Iran, 1973.

65. National Iranian Oil Company (NIOC). Tectonic Map of South-West Iran, 1: 2,500,000 Scale; NIOC: Tehran, Iran, 1977.

66. National Aeronautics and Space Administration (NASA). About Landsat: Enhanced Thematic Mapper Plus. 2012. Available online: http://landsat.gsfc.nasa.gov/about/etm +.html (accessed on 9 July 2019).

67. Iranian Oil Operating Companies (IOOC). Geological Compilation Map, 1:100000 Scale, Sheet No. 20824 E, Mulla Sani; IOOC, Geological and Exploration Division: Tehran, Iran, 1969.

68. Sherkati, S.; Letouzey, J. Variation of structural style and basin evolution in the central Zagros (Izeh zone and Dezful Embayment), Iran. Mar. Pet. Geol. 2004, 21, 535-554. [CrossRef]

69. Abdollahie Fard, I.; Braathen, A.; Mokhtari, M.; Alavi, S.A. Interaction of the Zagros Fold-Thrust Belt and the Arabian-type, deep-seated folds in the Abadan Plain and the Dezful Embayment, SW Iran. Pet. Geosci. 2006, 12, 347-362. [CrossRef]

70. Maleki, M.; Javaherian, A.; Abdollahi Fard, I. High porosity anomaly with good reservoir properties in the lower Fahliyan formation (Neocomian) of Darquain Field (SW Iran) by 3D seismic. J. Earth Space Phys. 2006, 32, 33-39.

71. Soleimani, B.; Nazari, K.; Bakhtiar, H.A.; Haghparast, G.; Zandkarimi, G. Three-Dimensional Geostatistical Modeling of Oil Reservoirs: A Case Study from the Ramin Oil Field in Iran. J. Appl. Sci. 2008, 8, 4523-4532.

72. Hogan, D.L.; Luzi, D.S. Channel Geomorphology: Fluvial Forms, Processes and Forest Management Effects. In Compendium of Forest Hydrology and Geomorphology in British Columbia; Volume 1 of 2. (British Columbia Land Management Handbook No. 66); Pike, R.G., Redding, T.E., Moore, R.D., Winkler, R.D., Bladon, K.D., Eds.; Forest Science Program and FORREX: Victoria, BC, Canada, 2010; pp. 331-372.

73. Bridge, J.S. Rivers and Floodplains: Form, Processes, and Sedimentary Record; Blackwell Science: Malden, MA, USA, 2003; p. 491.

74. Rogerson, P.A. Statistical Methods for Geography: A Student's Guide; SAGE Publications: London, UK, 2006; p. 304.

75. Rosgen, D.L. A classification of natural rivers. Catena 1994, 22, 169-199. [CrossRef]

76. Bjerklie, D.M.; Moller, D.; Smith, L.C.; Dingman, S.L. Estimating discharge in rivers using remotely sensed hydraulic information. J. Hydrol. 2005, 309, 191-209. [CrossRef]

77. Makaske, B. Anastomosing rivers: A review of their classification, origin and sedimentary products. Earth Sci. Rev. 2011, 53, 149-196. [CrossRef] 
78. Nanson, G.C.; Croke, J.C. A genetic classification of floodplains. Geomorphology 1992, 4, 459-486. [CrossRef]

79. Howard, A.D.; Keetch, M.E.; Vincent, C.L. Topological and Geometrical Properties of Braided Streams. Water Resour. Res. 1970, 6, 1674-1688. [CrossRef]

80. Chew, L.C.; Ashmore, P.E. Channel adjustment and a test of rational regime theory in a proglacial braided stream. Geomorphology 2001, 37, 43-63. [CrossRef]

81. Egozi, R.; Ashmore, P. Defining and measuring braiding intensity. Earth Surf. Process. Landf. 2008, 33, 2121-2138. [CrossRef]

82. Bretis, B.; Bartl, N.; Grasemann, B. Lateral fold growth and linkage in the Zagros fold and thrust belt (Kurdistan, NE Iraq). Basin Res. 2011, 23, 615-630. [CrossRef]

83. Selby, M.J. A rock mass strength classification for geomorphic purposes: With tests from Antarctica and New Zealand. Z. Geomorphol. NF 1980, 24, 31-51.

84. Ali, S.A.; Rangzan, K.; Pirasteh, S. Remote Sensing and GIS study of tectonics and net erosion rates in the Zagros Structural Belt, Southwestern Iran. Mapp. Sci. Remote Sens. 2003, 40, 258-267. [CrossRef]

85. Ali, S.A.; Pirasteh, S. Geological application of LANDSAT ETM for mapping structural geology and interpretation: Aided by Remote Sensing and GIS. Int. J. Remote Sens. 2004, 25, 4715-4727. [CrossRef]

86. VanLaningham, S.; Meigs, A.; Goldfinger, C. The effects of rock uplift and rock resistance on river morphology in a subduction zone forearc, Oregon, USA. Earth Surf. Processes Landf. 2006, 31, 1257-1279. [CrossRef]

87. Beyeler, J.D.; Sklar, L.S. Bedrock Resistance to fluvial Erosion: The Importance of Rock Tensile Strength, Crystal Grain Size and Porosity in Scaling from the Laboratory to the Field; Abstract EP41D-0740; American Geophysical Union, Fall Meeting Supplement: Washington, DC, USA, 2010; p. 91.

88. Lamb, M.P.; Finnegan, N.J.; Scheingross, J.S.; Sklar, L.S. New insights into the mechanics of fluvial bedrock erosion through flume experiments and theory. Geomorphology 2015, 244, 33-55. [CrossRef]

89. Walstra, J.; Heyvaert, V.M.A.; Verkinderen, P. Mapping the alluvial landscapes of lower Khuzestan (SW Iran). In Geomorphological Mapping: Methods and Applications; Smith, M.J., Paron, P., Griffith, J.S., Eds.; Elsevier: Amsterdam, The Netherlands, 2011; pp. 551-575.

90. Burnett, A.W. Alluvial Stream Response to Neotectonics in the Lower Mississippi Valley. Unpublished Master's Thesis, Colorado State University, Fort Collins, CO, USA, 1982; p. 182.

91. Santillan, J.R.; Makinano-Santillan, M. Vertical accuracy assessment of 30-m resolution ALOS, ASTER, and SRTM Global DEMs over Northeastern Mindanao, Philippines. Int. Arch. Photogramm. Remote. Sens. Spat. Inf. Sci. 2016, XLI-B4, 149-156, XXIII ISPRS Congress, Prague, Czech Republic, 12-19 July 2016. [CrossRef]

92. Giardino, J.R.; Lee, A.A. Rates of Channel Migration on the Brazos River; Final Report Contact No. 0904830898 submitted to the Texas Water Development Board; Texas A\&M University: College Station, TX, USA, 2011; p. 45.

93. Keller, E.A.; Pinter, N. Active Tectonics: Earthquakes, Uplift and Landscape; Prentice-Hall: Upper Saddle River, NJ, USA, 1996; p. 338.

94. Marín-Lechado, C.; Galindo-Zaldívar, J.; Gil, A.J.; Borque, M.J.; De Lacy, M.C.; Pedrera, A.; López-Garrido, A.C.; Alfaro, P.; García-Tortosa, F.; Ramos, M.I.; et al. Levelling Profiles and a GPS Network to Monitor the Active Folding and Faulting Deformation in the Campo de Dalias (Betic Cordillera, Southeastern Spain). Sensors 2010, 10, 3504-3518. [CrossRef]

95. Tatar, M.; Hatzfeld, D.; Martinod, J.; Walpersdorf, A.; Ghafori-Ashtiany, M.; Chéry, J. The present-day deformation of the central Zagros from GPS measurements. Geophys. Res. Lett. 2002, 29, 33-41. [CrossRef]

96. Serpelloni, E.; Faccenna, C.; Spada, G.; Dong, D.; Williams, S.D.P. Vertical GPS ground motion rates in the Euro-Mediterranean region: New evidence of velocity gradients at different spatial scales along the Nubia-Eurasia plate boundary. J. Geophys. Res. Solid Earth 2013, 118, 6003-6024. [CrossRef]

97. Rockwell, T.K.; Keller, E.A.; Dembroff, G.R. Quaternary rate of folding of the Ventura Avenue anticline, western Transverse Ranges, southern California. Bull. Geol. Soc. Am. 1988, 100, 800-858. [CrossRef]

98. Reyss, J.L.; Pirazolli, P.A.; Haghipour, A.; Hatté, C.; Fontugne, M. Quaternary marine terraces and tectonic uplift rates on the south coast of Iran. In Coastal Tectonics. Geological Society of London; Stewart, I.S., Vita-Finzi, C., Eds.; Special Publication No. 146; Geological Society of London: Bath, UK, 1998; pp. 225-237.

99. Lees, G.M.; Falcon, N.L. The Geographical History of the Mesopotamian Plains. Geogr. J. 1952, 118, $24-39$. [CrossRef]

100. Soleimany, B.; Poblet, J.; Bulnes, M.; Sàbat, F. Fold amplification history unravelled from growth strata: The Dorood anticline, NW Persian Gulf. J. Geol. Soc. Lond. 2011, 168, 219-234. [CrossRef] 
101. Khuzestan Water and Power Authority (KWPA). The Khuzistan Water and Power Authority Unpublished Résumé of the KWPA and Dams in Khuzestan; KWPA: Ahvaz, Iran, 2010; p. 11.

102. Verkinderen, P. Waterways of Iraq and Iran in the Early Islamic Period: Changing Rivers and Landscapes of the Mesopotamian Plain; I. B. Tauris: London, UK, 2015; p. 366.

103. Barry, R.G.; Chorley, R.J. Atmosphere, Weather and Climate, 6th ed.; Routledge: London, UK, 1992; p. 392.

104. Kottek, M.; Grieser, J.; Beck, C.; Rudolf, B.; Rubel, F. World Map of the Köppen-Geiger climate classification updated. Meteorol. Z. 2006, 15, 259-263. [CrossRef]

105. Alijani, B. Effect of the Zagros Mountains on the Spatial Distribution of Precipitation. J. Mt. Sci. 2008, 5, 218-231. [CrossRef]

106. Djamali, M.; Akhani, H.; Andrieu-Ponel, V.; Braconnot, P.; Brewer, S.; De Beaulieu, J.-L.; Fleitmann, D.; Fleury, J.; Gasse, F.; Guibal, F.; et al. Indian Summer Monsoon variations could have affected the Early-Holocene woodland expansion in the Near East. Holocene 2010, 20, 813-820. [CrossRef]

107. James, G.A.; Wynd, J.G. Stratigraphic nomenclature of Iranian Oil Consortium Agreement Area. Bull. Am. Assoc. Pet. Geol. 1965, 49, 2182-2245.

108. Falcon, N.L. Southern Iran: Zagros Mountains. In Mesozoic Cenozoic Orogenic Belts: Data for Orogenic Studies; Spencer, A.M., Ed.; Geological Society Special Publication No. 4; Scottish Academic Press: Edinburgh, UK, 1974; pp. 199-211.

109. Haynes, S.J.; McQuillan, H. Evolution of the Zagros Suture Zone, Southern Iran. Bull. Geol. Soc. Am. 1974, 85, 739-744. [CrossRef]

110. Alavi, M. Tectonics of the Zagros orogenic belt of Iran: New data and interpretations. Tectonophysics 1994, 229, 211-238. [CrossRef]

111. Berberian, M. Master "blind" thrust faults hidden under the Zagros folds: Active basement tectonics and surface morphotectonics. Tectonophysics 1995, 241, 193-224. [CrossRef]

112. Edgell, H.S. Salt tectonism in the Persian Gulf Basin. In Salt Tectonics; Alsop, G.I., Blundell, D.J., Davison, I., Eds.; Special Publication No. 100; Geological Society of London: Bath, UK, 1996; pp. 129-151.

113. Hamzepour, B.; Paul, D.J.; Wiesner, E.K. Views on the structural development of the Zagros simply folded Belt in Khuzestan Province, Iran. Z. Dtsch. Geol. Ges. 1999, 150, 167-188.

114. Hessami, K.; Koyi, H.A.; Talbot, C.J.; Tabasi, H.; Shabanian, E. Progressive unconformities within an evolving fold-thrust belt, Zagros Mountains. J. Geol. Soc. Lond. 2001, 158, 969-981. [CrossRef]

115. Hatzfeld, D.; Authemayou, C.; Van der Beek, P.; Bellier, O.; Lavé, J.; Oveisi, B.; Tatar, M.; Tavakoli, F.; Walpersdorf, A.; Yamini-Fard, F. The kinematics of the Zagros Mountains (Iran). In Tectonic and Stratigraphic Evolution of Zagros and Makran During the Mesozoic-Cenozoic; Leturmy, P., Robin, C., Eds.; Special Publication No. 330; Geological Society of London: Bath, UK, 2010; pp. 19-42.

116. Sella, G.F.; Dixon, T.H.; Mao, A. Revel: A model for Recent plate velocities from space geodesy. J. Geophys. Res. 2002, 107. [CrossRef]

117. Blanc, E.J.-P.; Allen, M.B.; Inger, S.; Hassani, H. Structural styles in the Zagros Simple Folded Zone, Iran. J. Geol. Soc. Lond. 2003, 160, 401-412. [CrossRef]

118. Allen, M.; Jackson, J.; Walker, R. Late Cenozoic reorganization of the Arabia-Eurasia collision and the comparison of short-term and long-term deformation rates. Tectonics 2004, 23, TC2008. [CrossRef]

119. Allen, M.B.; Saville, C.; Blanc, J.-P.; Talebian, M.; Nissen, E. Orogenic plateau growth: Expansion of the Turkish-Iranian Plateau across the Zagros fold-and-thrust belt. Tectonics 2013, 32, 1-20. [CrossRef]

120. Soleimany, B.; Sàbat, F. Style and age of deformation in the NW Persian Gulf. Pet. Geosci. 2010, 16, 31-39. [CrossRef]

121. Upton, G.; Cook, I. Understanding Statistics; Oxford University Press: Oxford, UK, 1996; p. 657.

122. Salkind, N.J. Statistics for People Who (Think They) Hate Statistics, 2nd ed.; SAGE Publications: London, UK, 2010 ; p. 398.

123. Lahiri, S.K.; Sinha, R. Tectonic controls on the morphodynamics of the Brahmaputra River system in the upper Assam valley, India. Geomorphology 2012, 167, 74-85. [CrossRef]

124. Keller, E.A.; Zepeda, R.L.; Rockwell, T.K.; Ku, T.L.; Dinklage, W.S. Active tectonics at Wheeler Ridge, southern San Joaquin Valley, California. Bull. Geol. Soc. Am. 1998, 110, 298-310. [CrossRef]

125. Keller, E.A.; Gurrola, L.; Tierney, T.E. Geomorphic criteria to determine direction of lateral propagation of reverse faulting and folding. Geology 1999, 27, 515-518. [CrossRef] 
126. Hurtrez, J.-E.; Lucazeau, F.; Lavé, J.; Avouac, J.-P. Investigation of the relationships between basin morphology, tectonic uplift, and denudation from the study of an active fold belt in the Siwalik Hills, central Nepal. J. Geophys. Res. 1999, 104, 12779-12796. [CrossRef]

127. Montgomery, D.R.; Stolar, D.B. Reconsidering Himalayan river anticlines. Geomorphology 2006, 82, 4-15. [CrossRef]

128. Simpson, G. Role of river incision in enhancing deformation. Geology 2004, 32, 341-344. [CrossRef]

129. Sklar, L.S.; Dietrich, W.E. Sediment and rock strength controls on river incision into bedrock. Geology 2001, 29, 1087-1090. [CrossRef]

130. Babault, J.; Van den Driessche, J.; Teixell, A. Longitudinal to transverse drainage network evolution in the High Atlas (Morocco): The role of tectonics. Tectonics 2012, 31, TC4020. [CrossRef]

(C) 2019 by the authors. Licensee MDPI, Basel, Switzerland. This article is an open access article distributed under the terms and conditions of the Creative Commons Attribution (CC BY) license (http://creativecommons.org/licenses/by/4.0/). 